\title{
Theoretical Design of Complex Molecule via Combination of Natural Lawsone and Synthetic Indoline D131 Dyes for Dye Sensitized Solar Cells Application
}

\author{
Nyanda Madili, Alexander Pogrebnoi, Tatiana Pogrebnaya \\ Department of Materials, Energy Science and Engineering, The Nelson Mandela African Institution of Science and Technology, \\ Arusha, Tanzania \\ Email:madilin@nm-aist.ac.tz, alexander.pogrebnoi@nm-aist.ac.tz,pgamtp@mail.ru, \\ tatiana.pogrebnaya@nm-aist.ac.tz,pgtp54@mail.ru
}

How to cite this paper: Madili, N., Pogrebnoi, A. and Pogrebnaya, T. (2018) Theoretical Design of Complex Molecule via Combination of Natural Lawsone and Synthetic Indoline D131 Dyes for Dye Sensitized Solar Cells Application. Computational Chemistry, 6, 87-112.

https://doi.org/10.4236/cc.2018.64007

Received: August 14, 2018

Accepted: October 28, 2018

Published: October 31, 2018

Copyright $\odot 2018$ by authors and Scientific Research Publishing Inc. This work is licensed under the Creative Commons Attribution International License (CC BY 4.0).

http://creativecommons.org/licenses/by/4.0/

\begin{abstract}
The dye sensitized solar cells (DSSCs) have been extensively studied due to their low production cost and simple fabrication process. Dye co-sensitization broadens the absorption spectrum of the sensitizer; thus enhances light harvesting efficiency; and contributes to the improvement of the DSSCs overall efficiency. In this study we performed theoretical design of complex molecule $\left(\mathrm{C}_{45} \mathrm{H}_{32} \mathrm{~N}_{2} \mathrm{O}_{4}\right)$ through combination (esterification reaction) of the natural dye lawsone and synthetic metal free indoline dye D131. The excitation energies, vibration spectra, molecular structures, electronic absorption spectra and electron transitions in individual dyes and complex molecule were investigated using density functional theory (DFT) and time dependent density functional theory (TD-DFT) B3LYP5 methods, with 3-21G, 6-31G and 6-31G(d,p) basis sets. The UV-Vis absorption spectra of the individual dyes and their mixture in chloroform solution were measured using spectrophotometer. For the complex formation reaction, enthalpy, entropy and Gibbs free energy were calculated and the results indicated the reaction was endothermic and non-spontaneous. Electron density distribution of the frontier and adjacent molecular orbitals and energy levels alignment were used for analysis of the electronic spectra and mechanism of transitions. The results indicated that the designed complex molecule satisfied the requirements for good photosensitizer of DSSCs.
\end{abstract}

\section{Keywords}

DSSCs, Lawsone, Indoline D131, Molecular Design, IR Spectra, UV-Vis 


\section{Introduction}

Due to increase in the environmental pollution and limited resource of fossil fuel, the development of solar energy harvesting is considered as a promising technology to substitute the fossil fuel, eliminate environmental pollution and sustain development of human societies.

DSSCs have attracted substantial attention, not only because of their environmental friendliness, low manufacturing cost, simple fabrication process and tunable aesthetic color, but also due to their lower dependence on the angle of incident light and higher efficiency under low irradiance compared to traditional Si-based solar cells [1]-[7]. DSSC is composed of two sandwiched electrodes, working and counter electrode which is made of transparent conducting glass mainly composed of fluorine doped tin oxide (FTO) or indium doped tin oxide. Working electrode is made of thin layer of semiconducting materials such as titanium dioxide $\left(\mathrm{TiO}_{2}\right)$, zinc oxide $(\mathrm{ZnO})$, tin dioxide $\left(\mathrm{SnO}_{2}\right)$ coated with dyes on top of FTO [8] [9]. Counter electrode is made of FTO with thin layer of platinum or carbon [10]. Electrolyte is placed between counter electrode and photoelectrode to mediate electrons [11]. Among of these components of DSSC, the sensitizer (dye) is a crucial element which plays a significant role in light capturing, electron injection and dye regeneration which impact on power conversion efficiency (PCE) as well as the stability of the devices.

However DSSCs are emerging as potential candidates for next generation solar cells owing to low-cost production process [12] but they face challenges regarding sensitizer such as high price of some dyes, dye degradation, and toxicity of some dyes [13]. Since the invention of DSSCs in the year of 1991 by Brian O'Regan and Michael Grätzel [4], ruthenium complexes [14] [15], metal-free organic dyes sensitizers [1] [16] [17] [18] [19] and natural dyes [20] [21] [22] have been investigated.

Although the Incident Photon to Charge Carrier Efficiency (IPCE) of DSSCs based on ruthenium dyes has reached $12 \%$ [23] [24] [25] under simulated AM 1.5 irradiation $\left(100 \mathrm{~mW} \cdot \mathrm{cm}^{-2}\right)$, ruthenium is rare, expensive, and toxic in nature that limits its potentially wide application. Despite the highest efficiency of $13 \%$ [26] has been reported for DSSCs based on free metal dyes (organic dyes), the high price hampers their extensive use. DSSCs based on natural dyes have poor photoelectrochemical properties but the natural dye sensitizers are cheap and environmentally friendly.

To overcome challenges facing DSSCs, theoretical and experimental studies of physical and chemical properties of dyes are required as they contribute to understanding the relationship between structure, properties of dyes and performance of a solar cell and hence facilitate design and synthesis of efficient dyes 
for DSSCs application [20] [27]-[32]. In selecting and designing an efficient dye, electron donating part, unit to adjust the absorption spectrum and the electron-acceptor part of the dye [33] must be taken into design consideration. Mainly the dye to be an efficient sensitizer should be designed with a target of eliminating dye aggregation, minimizing dye recombination and maximizing the driving force for electron injection from the dye to the semiconductor and driving force for dye regeneration, broaden up the absorption spectra which finally improve the overall efficiency of the DSSCs [34] [35] [36]. Combination of dyes with different absorption properties has been investigated intending to enhance light harvesting efficiency as well as general performance of DSSCs [37]-[42].

In this study, the effect of combination of natural dye lawsone and synthetic metal free indoline D131 dye for the purpose of utilization in DSSCs has been investigated. The computations of vibrational and electronic absorption spectra of the indoline D131, lawsone and designed complex molecule as well as mechanisms of electron transitions and energy levels alignment are included in the theoretical part. The UV-Vis spectra of the individual dyes solutions and their mixture are considered in the experimental part.

\section{Materials and Methods}

\subsection{Computational Details}

The initial coordinates of indoline and lawsone dyes were taken from ChemSpider database [43] and NIST [44], respectively. The geometrical parameters were optimized using density function theory DFT/B3LYP5 with the different basis sets, 3-21G, 6-31G and 6-31G(d,p). The optimized coordinates were used as inputs for computation of vibrational and electronic spectra.

The complex dye molecule $\mathrm{C}_{45} \mathrm{H}_{32} \mathrm{~N}_{2} \mathrm{O}_{4}$ was designed through modeling of esterification reaction between indoline D131 and lawsone dyes. The structure of the designed dye was optimized using DFT/B3LYP5 starting from the lowest STO-3G through 3-21G, 6-31G to highest 6-31G(d,p) basis set. The energy, Gibbs free energy and enthalpy of the complex formation reaction

$$
\mathrm{C}_{35} \mathrm{H}_{28} \mathrm{~N}_{2} \mathrm{O}_{2}+\mathrm{C}_{10} \mathrm{H}_{6} \mathrm{O}_{3} \rightarrow \mathrm{C}_{45} \mathrm{H}_{32} \mathrm{~N}_{2} \mathrm{O}_{4}+\mathrm{H}_{2} \mathrm{O}
$$

were computed at different basis sets with the corresponding optimized coordinates. The energy of the reaction $\Delta_{\mathrm{r}} E$ was calculated as a difference between the total energies of the products and reactants:

$$
\Delta_{\mathrm{r}} E=\sum E_{\text {prod }}-\sum E_{\text {react }}
$$

In quantum chemical computations, the total energies of species correspond to temperature $0 \mathrm{~K}$ and normal pressure. The enthalpy of the reaction $\Delta_{\mathrm{r}} H^{\circ}(0)$ was found using the $\Delta_{I} E$ and zero point vibration energy (ZPVE) $\Delta_{r} \mathcal{E}$

$$
\begin{gathered}
\Delta_{\mathrm{r}} H^{\circ}(0)=\Delta_{\mathrm{r}} E+\Delta_{\mathrm{r}} \varepsilon \\
\Delta_{r} \varepsilon=\frac{1}{2} h c\left(\sum \omega_{i \text { prod }}-\sum \omega_{i \text { react }}\right)
\end{gathered}
$$

where $h$ is the Plank's constant, $c$ is the speed of light in free space, $\sum \omega_{i \text { prod }}$ 
and $\sum \omega_{i \text { react }}$ are the sums of the vibrational frequencies of the products and reactants, respectively. The Gibbs free energy $\Delta_{\mathrm{r}} G^{\circ}(T)$ of the reaction was obtained by the following equations:

$$
\begin{gathered}
\Delta_{\mathrm{r}} G^{\circ}(T)=\Delta_{\mathrm{r}} H^{\circ}(T)-T \Delta_{\mathrm{r}} S^{\circ}(T) \\
\Delta_{\mathrm{r}} H^{\circ}(T)=\Delta_{\mathrm{r}} H^{\circ}(0)+\Delta_{r}\left[H^{\circ}(T)-H^{\circ}(0)\right]
\end{gathered}
$$

where $\Delta_{\mathrm{r}} H^{\circ}(T)$ and $\Delta_{\mathrm{r}} S^{\circ}(T)$ are the enthalpy and entropy of the reaction at temperature $T$. The thermodynamic functions, entropies $S^{\circ}(T)$ and enthalpy increments $H^{\circ}(T)-H^{\circ}(0)$, of the participants of the reaction have been calculated with OpenThermo software [45].

The vertical excitation and electronic absorption spectra of the lawsone dye, indoline D131 dye and the designed complex molecules both in vacuum and solvent (chloroform) were computed at the TD-DFT B3LYP5/6-31G(d,p) level of theory. The solvent effects were accounted by employing the polarized continuum model (PCM). All quantum chemical computations were performed using the Firefly QC package [46] which is partially based on the GAMESS (US) source code [47]. The geometrical structures, vibrational and electronic spectra were visualized and analyzed using the Chemcraft [48] and MacMolPlt software [49].

\subsection{Experimental Details}

The indoline D131 dye with a purity of $97 \%$ and lawsone dye with purity $97 \%$ were bought in powder form from Sigma-Aldrich Chemical Company and were used without further purification for solution preparation at room temperature. A single solvent both for D131 and lawsone was needed. Chloroform was found to be appropriate solvent [50] [51]; it was bought from Sigma-Aldrich Chemical supplier.

The solutions of $1.15 \times 10^{-4} \mathrm{M}$ for lawsone and $2.95 \times 10^{-5} \mathrm{M}$ for indoline D131 were prepared and used for the UV-Vis spectra measurements. The mass 8 $\mathrm{mg}$ of lawsone dissolved in $40 \mathrm{ml}$ of chloroform to have $1.15 \times 10^{-3} \mathrm{M}$ and then 1 $\mathrm{ml}$ of the solution was added to $9 \mathrm{ml}$ of chloroform resulting in $1.15 \times 10^{-4} \mathrm{M}$. For the case of indoline D131 dye, $6 \mathrm{mg}$ of the sample was dissolved in $40 \mathrm{ml}$ of chloroform resulting in $2.95 \times 10^{-4} \mathrm{M}$, then $2 \mathrm{ml}$ of this solution was added to $18 \mathrm{ml}$ of chloroform to get $2.95 \times 10^{-5} \mathrm{M}$ indoline D131 solution. The solution of the dyes mixture was prepared by combination of the indoline D131 and lawsone dye solutions in the ratio of $1: 1$. The UV-Vis spectra of the samples were recorded in the region $190-820 \mathrm{~nm}$ on a single beam $2800 \mathrm{UV}$-Vis spectrophotometer (Hitachi U2000) with quartz cuvettes of $10 \mathrm{~mm}$ path length.

\section{Results and Discussion}

\subsection{Molecular Structure of Individual Dyes and Complex Molecule}

The equilibrium geometrical structures of lawsone, indoline D131 and the designed complex molecules computed at B3LYP5/6-31G(d,p) are given in Figure 1. 


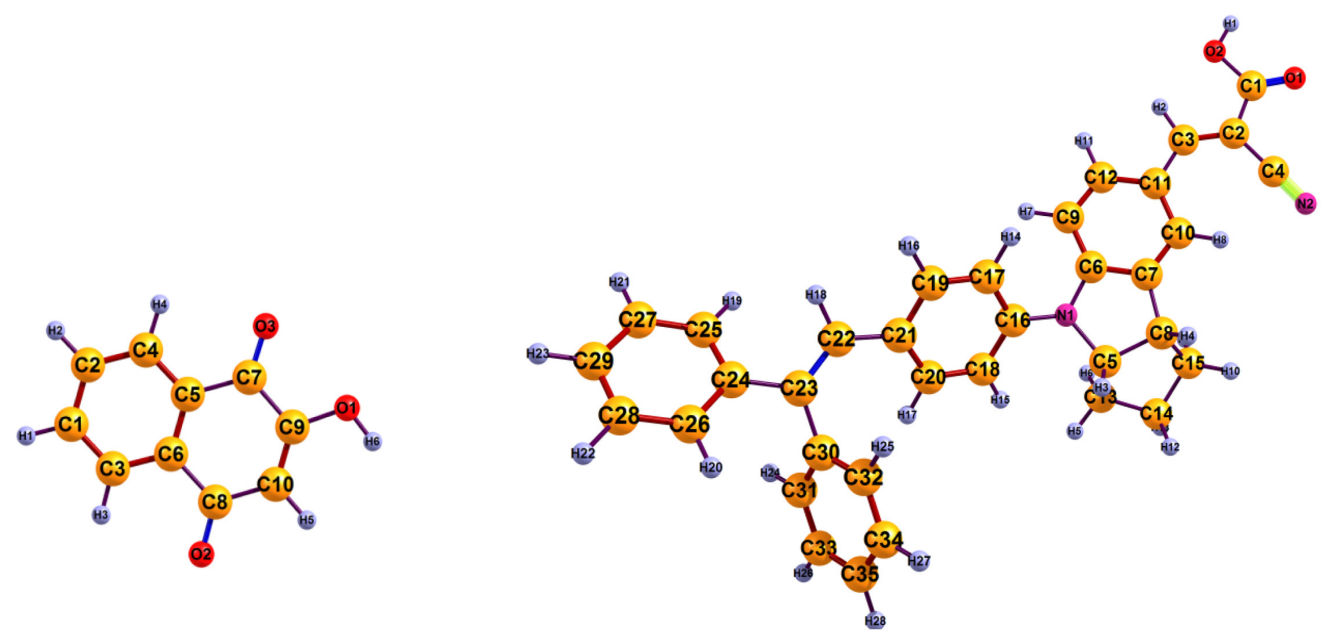

(a)

(b)

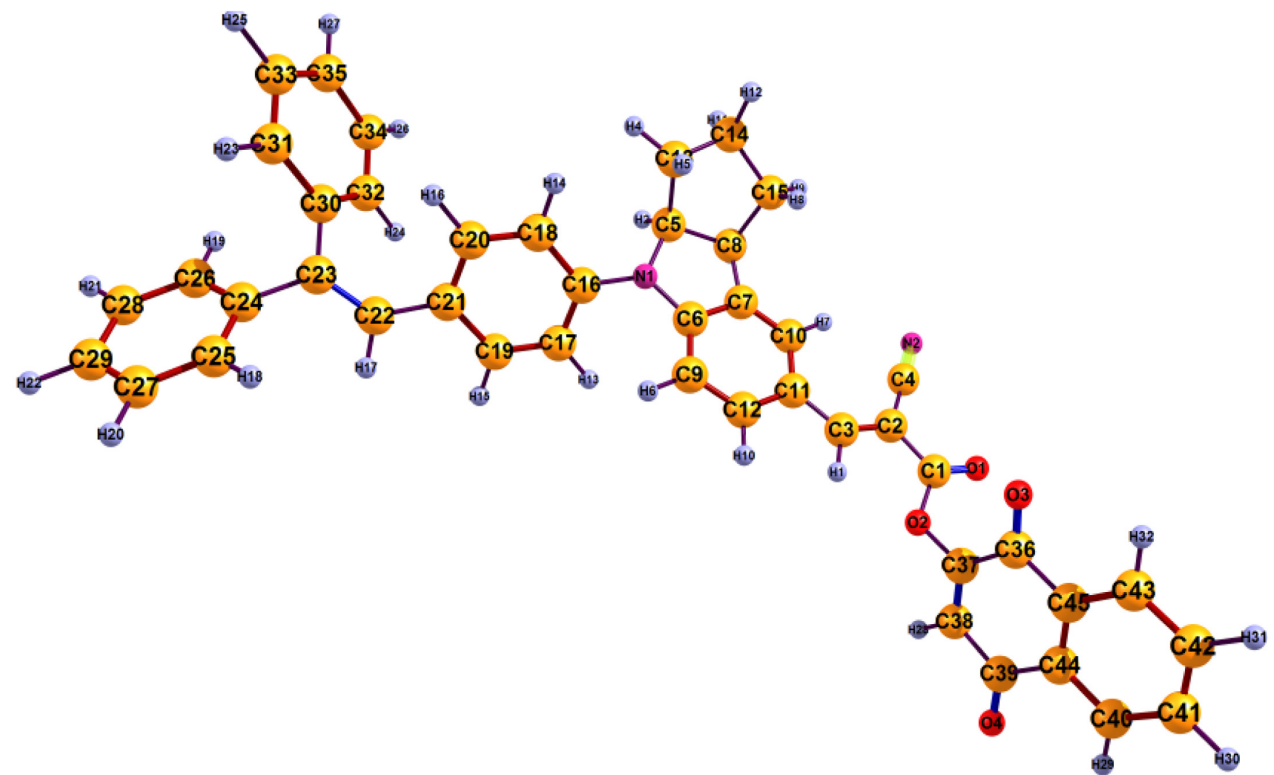

(c)

Figure 1. The optimized geometrical structure of molecules: (a) lawsone, (b) indoline D131, (c) complex. The visualization of molecular structures was performed by using the ChemCraft software [48].

The lawsone molecule (2-hydroxy-1, 4-naphthoquinone molecule) contains two six-membered rings, two ketone groups and one hydroxyl group (Figure 1(a)). Indoline dye D131 is composed of 4-(2, 2 diphenylethenyl) phenyl) substituent acting as a donor and $\pi$ conjugated to the indoline ring, cynoacrylic acid group as an acceptor [30] (Figure 1(b)).

In the complex molecule, the coupling of the molecules occurs via a new chemical bond C1-O2-C37 (Figure 1(c)). The formation of this bond is accompanied by detachment of the $\mathrm{H} 1$-atom from cynoacrylic acid group of indoline D131 dye and hydroxyl O1-H6 from lawsone dye to release water molecule. Schematic representation of $\mathrm{H}_{2} \mathrm{O}$ molecule detachment is shown below. 


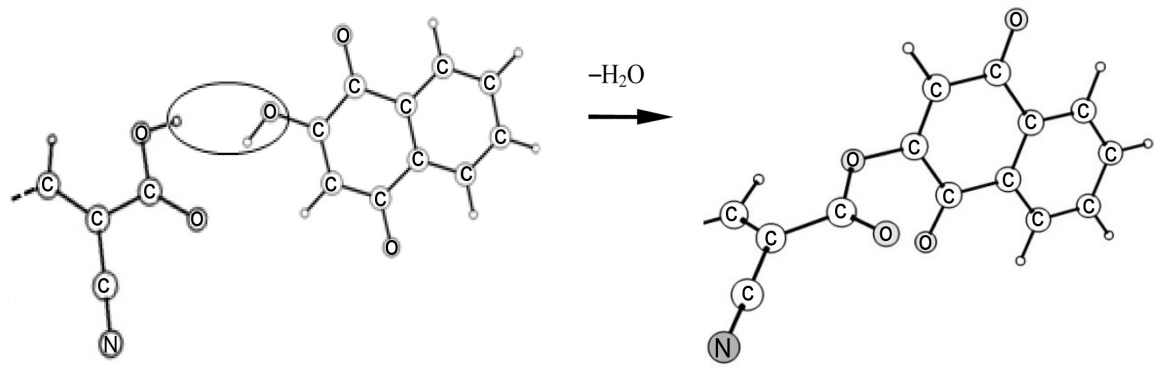

The selected geometrical parameters of the individual dyes are compared with those in the complex molecule in Table 1 and Table 2; the differences between respective parameters are shown in the far right columns. The bond C1-O2-C37

Table 1. Comparison of selected geometrical parameters of lawsone and complex molecule computed at B3LYP5/6-31G(d,p).

\begin{tabular}{|c|c|c|c|c|}
\hline \multicolumn{2}{|c|}{ Lawsone } & \multicolumn{2}{|c|}{ Complex molecule } & \multirow[t]{2}{*}{ Difference } \\
\hline \multicolumn{4}{|c|}{ Bond lengths, $\AA$} & \\
\hline C9-O1 & 1.344 & $\mathrm{C} 37-\mathrm{O} 2$ & 1.370 & +0.026 \\
\hline C9-C7 & 1.506 & C37-C36 & 1.502 & -0.004 \\
\hline $\mathrm{C} 7=\mathrm{O} 3$ & 1.221 & $\mathrm{C} 36=\mathrm{O} 3$ & 1.222 & +0.001 \\
\hline $\mathrm{C} 9=\mathrm{C} 10$ & 1.354 & $\mathrm{C} 37=\mathrm{C} 38$ & 1.345 & -0.009 \\
\hline $\mathrm{C} 10-\mathrm{C} 8$ & 1.467 & C38-C39 & 1.478 & +0.001 \\
\hline $\mathrm{C} 8=\mathrm{O} 2$ & 1.228 & $\mathrm{C} 39=\mathrm{O} 4$ & 1.227 & -0.001 \\
\hline C5-C6 & 1.407 & C45-C44 & 1.408 & +0.001 \\
\hline $\mathrm{C} 5-\mathrm{C} 4$ & 1.399 & $\mathrm{C} 45-\mathrm{C} 43$ & 1.399 & 0.000 \\
\hline $\mathrm{C} 4-\mathrm{C} 2$ & 1.393 & $\mathrm{C} 43-\mathrm{C} 42$ & 1.393 & 0.000 \\
\hline $\mathrm{C} 2-\mathrm{C} 1$ & 1.399 & $\mathrm{C} 42-\mathrm{C} 41$ & 1.399 & 0.000 \\
\hline $\mathrm{C} 1-\mathrm{C} 3$ & 1.394 & $\mathrm{C} 41-\mathrm{C} 40$ & 1.394 & 0.000 \\
\hline C3-C6 & 1.396 & $\mathrm{C} 40-\mathrm{C} 44$ & 1.397 & +0.001 \\
\hline \multicolumn{5}{|c|}{ Bond angles, degree } \\
\hline $\mathrm{O} 1-\mathrm{C} 9-\mathrm{C} 7$ & 112.8 & $\mathrm{O} 2-\mathrm{C} 37-\mathrm{C} 36$ & 116.4 & +3.6 \\
\hline O1-C9-C10 & 125.4 & $\mathrm{O} 2-\mathrm{C} 37-\mathrm{C} 38$ & 120.7 & -4.7 \\
\hline $\mathrm{C} 9-\mathrm{C} 7-\mathrm{O} 3$ & 120.4 & $\mathrm{C} 37-\mathrm{C} 36-\mathrm{O} 3$ & 120.4 & 0.0 \\
\hline $\mathrm{C} 10-\mathrm{C} 8-\mathrm{O} 2$ & 121.1 & C38-C39-O4 & 120.6 & -0.5 \\
\hline $\mathrm{O} 2-\mathrm{C} 8-\mathrm{C} 6$ & 121.4 & O4-C49-C44 & 121.9 & +0.5 \\
\hline C9-C10-C8 & 122.5 & C37-C38-C39 & 121.8 & -0.7 \\
\hline $\mathrm{C} 10-\mathrm{C} 9-\mathrm{C} 7$ & 121.9 & $\mathrm{C} 38-\mathrm{C} 37-\mathrm{C} 36$ & 122.5 & +0.6 \\
\hline O3-C7-C5 & 123.0 & O3-C36-C45 & 123.1 & +0.1 \\
\hline C9-C7-C5 & 116.6 & C37-C36-C45 & 116.5 & -0.1 \\
\hline C7-C5-C4 & 119.1 & C36-C45-C43 & 119.3 & +0.2 \\
\hline C4-C5-C6 & 119.9 & C43-C45-C44 & 120.0 & +0.1 \\
\hline C2-C4-C5 & 119.9 & C42-C43-C45 & 119.9 & 0.0 \\
\hline $\mathrm{C} 4-\mathrm{C} 2-\mathrm{C} 1$ & 120.1 & C43-C42-C41 & 120.2 & +0.1 \\
\hline C5-C6-C3 & 119.0 & C45-C44-C40 & 119.8 & +0.8 \\
\hline C6-C3-C1 & 120.0 & C44-C40-C41 & 120.0 & 0.0 \\
\hline $\mathrm{C} 3-\mathrm{C} 1-\mathrm{C} 2$ & 120.2 & C40-C41-C42 & 120.2 & 0.0 \\
\hline
\end{tabular}


Table 2. Comparison of selected geometrical parameters of indoline D131 dye and complex molecule computed at B3LYP5/6-31G(d,p).

\begin{tabular}{|c|c|c|c|c|}
\hline \multicolumn{2}{|c|}{ Indoline dye D131 } & \multicolumn{2}{|c|}{ Complex molecule } & \multirow[t]{2}{*}{ Difference } \\
\hline \multicolumn{4}{|c|}{ Bond lengths, $\AA$} & \\
\hline $\mathrm{C} 1=\mathrm{O} 1$ & 1.228 & $\mathrm{C} 1=\mathrm{O} 1$ & 1.206 & -0.022 \\
\hline $\mathrm{C} 1-\mathrm{O} 2$ & 1.391 & $\mathrm{C} 1-\mathrm{O} 2$ & 1.397 & +0.006 \\
\hline $\mathrm{C} 2-\mathrm{C} 1$ & 1.477 & $\mathrm{C} 2-\mathrm{C} 1$ & 1.476 & -0.001 \\
\hline $\mathrm{C} 2-\mathrm{C} 4$ & 1.417 & $\mathrm{C} 2-\mathrm{C} 4$ & 1.429 & +0.012 \\
\hline $\mathrm{C} 4 \equiv \mathrm{N} 2$ & 1.168 & $\mathrm{C} 4 \equiv \mathrm{N} 2$ & 1.165 & -0.003 \\
\hline $\mathrm{C} 2-\mathrm{C} 3$ & 1.366 & $\mathrm{C} 2-\mathrm{C} 3$ & 1.373 & +0.007 \\
\hline C3-C11 & 1.442 & $\mathrm{C} 3-\mathrm{C} 11$ & 1.439 & -0.003 \\
\hline $\mathrm{C} 11-\mathrm{C} 10$ & 1.424 & $\mathrm{C} 11-\mathrm{C} 10$ & 1.423 & -0.001 \\
\hline $\mathrm{C} 11-\mathrm{C} 12$ & 1.417 & $\mathrm{C} 11-\mathrm{C} 12$ & 1.422 & +0.005 \\
\hline C6-N1 & 1.387 & C6-N1 & 1.380 & -0.007 \\
\hline $\mathrm{C} 5-\mathrm{N} 1$ & 1.502 & $\mathrm{C} 5-\mathrm{N} 1$ & 1.496 & -0.006 \\
\hline $\mathrm{C} 16-\mathrm{N} 1$ & 1.411 & C16-N1 & 1.413 & +0.002 \\
\hline $\mathrm{C} 5-\mathrm{C} 8$ & 1.585 & $\mathrm{C} 5-\mathrm{C} 8$ & 1.578 & -0.007 \\
\hline $\mathrm{C} 5-\mathrm{C} 13$ & 1.557 & $\mathrm{C} 5-\mathrm{C} 13$ & 1.553 & -0.004 \\
\hline C17-C19 & 1.390 & $\mathrm{C} 17-\mathrm{C} 19$ & 1.392 & +0.002 \\
\hline $\mathrm{C} 23-\mathrm{C} 22$ & 1.356 & $\mathrm{C} 23-\mathrm{C} 22$ & 1.363 & +0.007 \\
\hline $\mathrm{C} 24-\mathrm{C} 25$ & 1.408 & $\mathrm{C} 24-\mathrm{C} 25$ & 1.412 & +0.004 \\
\hline $\mathrm{C} 23-\mathrm{C} 30$ & 1.496 & $\mathrm{C} 23-\mathrm{C} 30$ & 1.496 & 0.000 \\
\hline $\mathrm{C} 30-\mathrm{C} 32$ & 1.404 & $\mathrm{C} 30-\mathrm{C} 32$ & 1.409 & +0.005 \\
\hline $\mathrm{C} 32-\mathrm{C} 34$ & 1.397 & $\mathrm{C} 32-\mathrm{C} 34$ & 1.399 & +0.002 \\
\hline \multicolumn{5}{|c|}{ Bond angles, deg } \\
\hline $\mathrm{O} 1-\mathrm{C} 1-\mathrm{O} 2$ & 122.3 & $\mathrm{O} 1-\mathrm{C} 1-\mathrm{O} 2$ & 122.0 & -0.3 \\
\hline $\mathrm{C} 2-\mathrm{C} 1-\mathrm{O} 1$ & 125.9 & $\mathrm{C} 2-\mathrm{C} 1-\mathrm{O} 1$ & 126.1 & +0.2 \\
\hline $\mathrm{C} 2-\mathrm{C} 1-\mathrm{O} 2$ & 111.8 & $\mathrm{C} 2-\mathrm{C} 1-\mathrm{O} 2$ & 111.9 & +0.1 \\
\hline $\mathrm{C} 3-\mathrm{C} 2-\mathrm{C} 1$ & 120.3 & $\mathrm{C} 3-\mathrm{C} 2-\mathrm{C} 1$ & 121.8 & +1.5 \\
\hline $\mathrm{C} 3-\mathrm{C} 2-\mathrm{C} 4$ & 125.5 & $\mathrm{C} 3-\mathrm{C} 2-\mathrm{C} 4$ & 124.2 & -1.3 \\
\hline $\mathrm{C} 2-\mathrm{C} 4-\mathrm{N} 2$ & 179.2 & $\mathrm{C} 2-\mathrm{C} 4-\mathrm{N} 2$ & 178.7 & -0.5 \\
\hline $\mathrm{C} 11-\mathrm{C} 3-\mathrm{C} 2$ & 131.0 & $\mathrm{C} 11-\mathrm{C} 3-\mathrm{C} 2$ & 132.2 & +1.2 \\
\hline $\mathrm{C} 12-\mathrm{C} 11-\mathrm{C} 10$ & 118.0 & $\mathrm{C} 12-\mathrm{C} 11-\mathrm{C} 10$ & 117.8 & -0.2 \\
\hline $\mathrm{C} 6-\mathrm{C} 7-\mathrm{C} 8$ & 110.0 & C6-C7-C8 & 109.5 & -0.5 \\
\hline $\mathrm{C} 13-\mathrm{C} 5-\mathrm{C} 8$ & 104.5 & $\mathrm{C} 13-\mathrm{C} 5-\mathrm{C} 8$ & 105.0 & +0.5 \\
\hline C6-N1-C5 & 110.1 & C6-N1-C5 & 110.5 & +0.4 \\
\hline C16-N1-C6 & 126.9 & C16-N1-C6 & 125.9 & -1.0 \\
\hline C16-N1-C5 & 122.4 & C16-N1-C5 & 122.5 & +0.1 \\
\hline $\mathrm{C} 18-\mathrm{C} 16-\mathrm{C} 17$ & 118.1 & $\mathrm{C} 18-\mathrm{C} 16-\mathrm{C} 17$ & 118.2 & +0.1 \\
\hline $\mathrm{C} 23-\mathrm{C} 22-\mathrm{C} 21$ & 129.9 & $\mathrm{C} 23-\mathrm{C} 22-\mathrm{C} 21$ & 131.0 & +0.1 \\
\hline C30-C32-C34 & 120.3 & C30-C32-C34 & 120.7 & +0.4 \\
\hline C30-C31-C33 & 120.3 & C30-C31-C33 & 120.7 & +0.4 \\
\hline \multicolumn{5}{|c|}{ Dihedral angles, deg } \\
\hline $\mathrm{C} 10-\mathrm{C} 11-\mathrm{C} 2-\mathrm{C} 4$ & -0.3 & $\mathrm{C} 10-\mathrm{C} 11-\mathrm{C} 2-\mathrm{C} 4$ & -1.3 & +1.0 \\
\hline $\mathrm{C} 10-\mathrm{C} 11-\mathrm{C} 1-\mathrm{O} 1$ & -0.2 & $\mathrm{C} 10-\mathrm{C} 11-\mathrm{C} 1-\mathrm{O} 1$ & -4.4 & +4.2 \\
\hline C17-C16-C6-C9 & -40.5 & C17-C16-C6-C9 & -44.4 & +3.9 \\
\hline
\end{tabular}


in the complex is specified with parameters $R(\mathrm{C} 1-\mathrm{O} 2)=1.397 \AA$, $R(\mathrm{O} 2-\mathrm{C} 37)=$ $1.370 \AA$ and $\angle \mathrm{C} 1-\mathrm{O} 2-\mathrm{C} 37=117.0^{\circ}$; which are comparable with those of the ester C-O-C linkage, $1.43 \AA$ [52] [53] and $119^{\circ}$ [54]. The most noticeable change is observed in the vicinity of the new chemical bond: $+0.026 \AA$ (elongation) for C37-O2 bond in the lawsone moiety and $-0.022 \AA$ (shortening) for $\mathrm{C} 1=\mathrm{O} 1$ in the indoline part. The biggest change is seen in the bond angles, $+3.6^{\circ}$ $(\mathrm{O} 2-\mathrm{C} 37-\mathrm{C} 36)$ and $-4.7^{\circ}(\mathrm{O} 2-\mathrm{C} 37-\mathrm{C} 38)$ in the lawsone part, and in the dihedral angles, $3.9^{\circ}$ (C17-C16-C6-C9) and $+4.2^{\circ}(\mathrm{C} 10-\mathrm{C} 11-\mathrm{C} 1-\mathrm{O} 1)$ in the indoline part. The difference in other respective parameters is not significant; it does not exceed $0.009 \AA$ for bond lengths and $1.5^{\circ}$ for bond angles. The parameters of the far parts of the complex molecule remain almost the same as in the individual molecules.

The thermodynamic characteristics of the complex formation reaction (1): energy $\Delta_{\mathrm{r}} E$, zero point vibration energy $\Delta_{\mathrm{r}} \varepsilon$, enthalpies $\Delta_{\mathrm{r}} H^{\circ}(0)$ and $\Delta_{\mathrm{r}} H^{\circ}(298)$, Gibbs free energy $\Delta_{\mathrm{r}} G^{\circ}(298)$ and entropy $\Delta_{\mathrm{r}} S(298)$ computed at different basis sets are given in Table 3 .

As is seen, the extension of the basis set from 3-21G to 6-31G results in the decrease of the value of $\Delta_{\mathrm{r}} E$ by $15.3 \mathrm{~kJ} \cdot \mathrm{mol}^{-1}$ but the polarization functions addition does not influence much on this value. The values of enthalpy and Gibbs free energy follow the trend of the energy $\Delta_{\mathrm{r}} E$ as the ZPVE values are not much sensitive to the basis set change.

The values of enthalpies $\Delta_{\mathrm{r}} H^{\circ}$ are positive that implies the reaction (1) is endothermic. The entropy $\Delta_{\mathrm{r}} S^{\circ}(298)$ is negative hence depicting an increase of the order of the system. The Gibbs free energy $\Delta_{\mathrm{r}} G^{\circ}(298)$ being positive shows non-spontaneity of the complex formation through direct combination of the dye molecules.

\subsection{Vibrational Spectra of the Species}

The IR spectra of the individual dyes and complex molecule computed at B3LYP5/6-31G(d,p) are shown in Figures 2(a)-(c). The absence of imaginary frequencies proves that the geometrical structures of the species correspond to minima on the potential energy surfaces.

Table 3. The thermodynamic characteristics of the complex formation reaction (1): energy $\Delta_{\mathrm{r}} E$, zero point vibration energy $\Delta_{\mathrm{r}} \mathcal{E}$, enthalpies $\Delta_{\mathrm{r}} H^{\circ}(0)$ and $\Delta_{\mathrm{r}} H^{\circ}(298)$, Gibbs free energy $\Delta_{\mathrm{r}} G^{\circ}(298)$ and entropy $\Delta_{\mathrm{r}} S^{\circ}(298)$.

\begin{tabular}{cccc}
\hline Quantity & B3LYP5/3-21G & B3LYP5/6-31G & B3LYP5/6-31G(d,p) \\
\hline$\Delta_{\mathrm{r}} E, \mathrm{~kJ} \cdot \mathrm{mol}^{-1}$ & 56.0 & 39.5 & 40.7 \\
$\Delta_{\mathrm{r}} \mathcal{E}, \mathrm{kJ} \cdot \mathrm{mol}^{-1}$ & -12.6 & -11.4 & -10.7 \\
$\Delta_{\mathrm{r}} H^{\circ}(0), \mathrm{kJ} \cdot \mathrm{mol}^{-1}$ & 43.4 & 28.1 & 30.1 \\
$\Delta_{\mathrm{r}} H^{\circ}(298), \mathrm{kJ} \cdot \mathrm{mol}^{-1}$ & 49.7 & 34.3 & 36.0 \\
$\Delta_{\mathrm{r}} G^{\circ}(298), \mathrm{kJ} \cdot \mathrm{mol}^{-1}$ & 53.5 & 37.6 & 41.1 \\
$\Delta_{\mathrm{r}} S^{\circ}(298), \mathrm{J} \cdot \mathrm{mol}^{-1} \cdot \mathrm{K}^{-1}$ & -12.7 & -11.2 & -17.3 \\
\hline
\end{tabular}




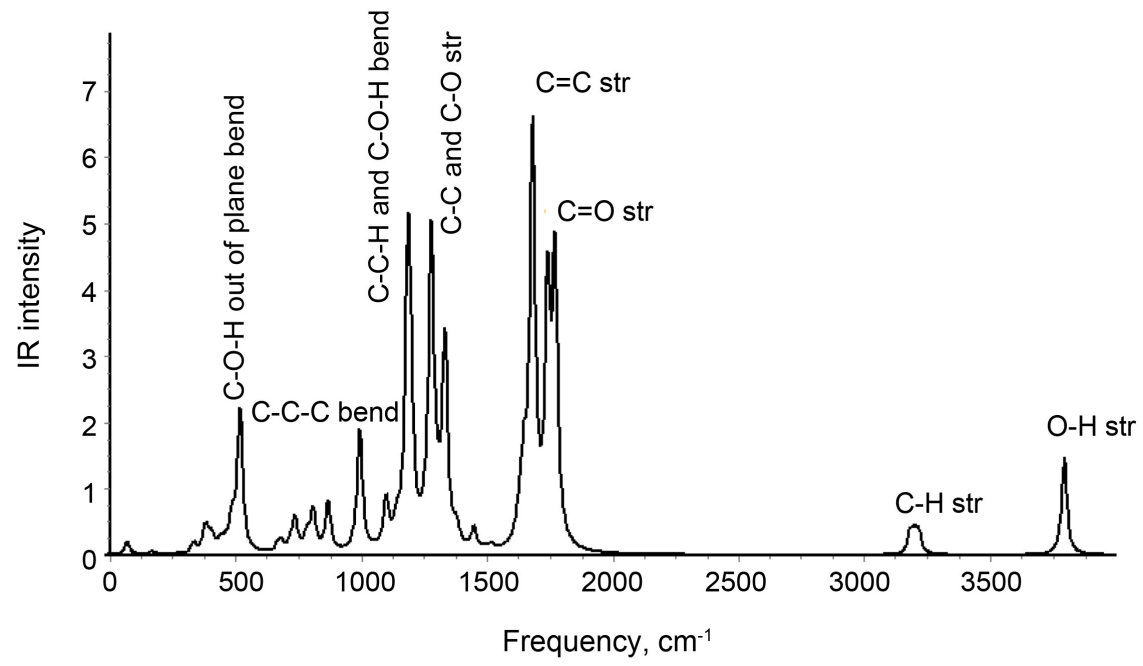

(a)

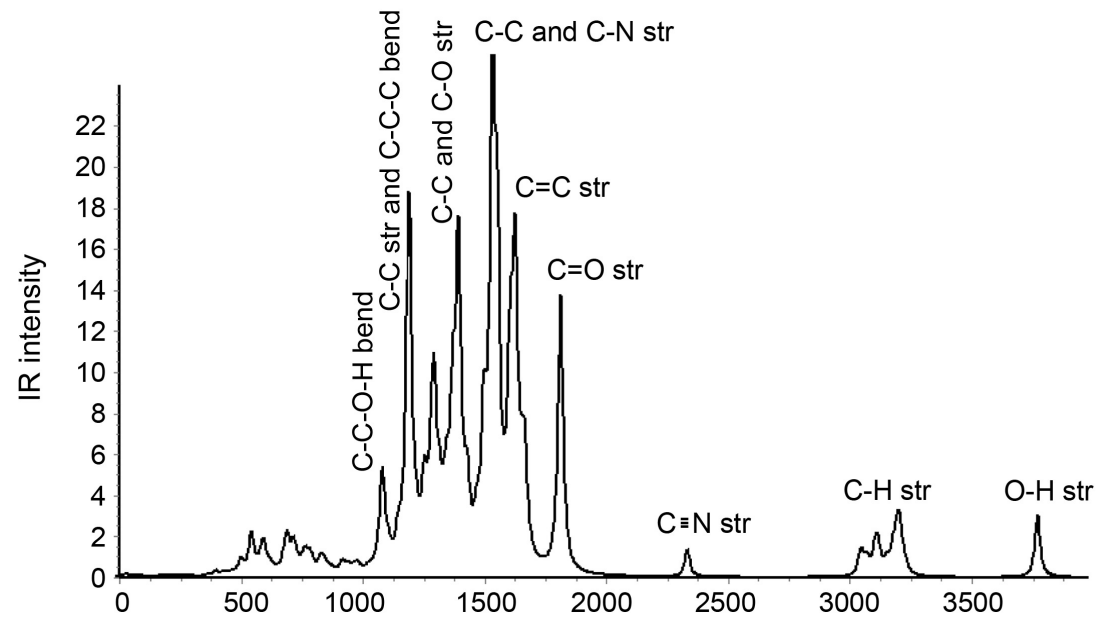

Frequency, $\mathrm{cm}^{-1}$

(b)

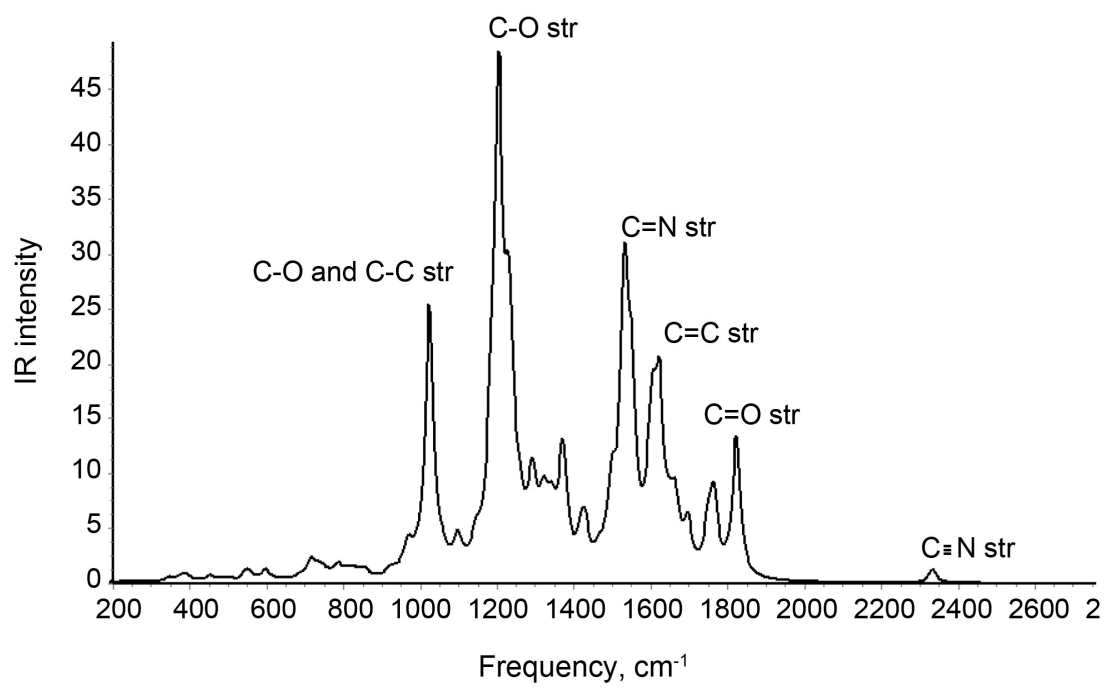

(c)

Figure 2. The IR spectra of molecules: (a) lawsone, (b) indoline D131, (c) complex. 
The most intensive modes in the spectrum of lawsone are assigned to vibrations $1680 \mathrm{~cm}^{-1}$ (C=C stretching), $1280 \mathrm{~cm}^{-1}$ (C-C and C-O stretching), 1740 and $1770 \mathrm{~cm}^{-1}$ (C=O stretching), $1180 \mathrm{~cm}^{-1}$ (C-C-H and C-O-H bending), $990 \mathrm{~cm}^{-1}$ (C-C-C bending), $520 \mathrm{~cm}^{-1}$ (C-O-H out of plane bend), and $3800 \mathrm{~cm}^{-1}(\mathrm{O}-\mathrm{H}$ stretching); and those in indoline are $1530-1550 \mathrm{~cm}^{-1}$ (C-C and C-N stretching in cycles), $1390 \mathrm{~cm}^{-1}$ (C-C and C-O stretching near carboxylic group), $1810 \mathrm{~cm}^{-1}$ ( $\mathrm{C}=\mathrm{O}$ stretching), $1190 \mathrm{~cm}^{-1}$ (C-C stretching and $\mathrm{C}-\mathrm{C}-\mathrm{C}$ bending near carboxylic group), $1080 \mathrm{~cm}^{-1}$ (C-C-O-H bending), $3770 \mathrm{~cm}^{-1}$ (O-H stretching). All these frequencies are close to typical vibrational wavenumbers of the respective functional groups.

The IR spectrum of the complex molecule apparently contains the vibrational modes of the lawsone part, e.g., $1763 \mathrm{~cm}^{-1}$ ( $\mathrm{C}=\mathrm{O}$ stretching), $1696 \mathrm{~cm}^{-1}(\mathrm{C}=\mathrm{C}$ stretching), and indoline part, $1820 \mathrm{~cm}^{-1}\left(\mathrm{C}=\mathrm{O}\right.$ stretching) and $1530-1550 \mathrm{~cm}^{-1}$ (C-C and C-N stretching), but these modes slightly differ from those of the individual dyes.

The uniqueness of the spectrum in comparison to individual dyes is the appearance of very intensive bands which relate to the new formed C37-O2-C1 bond, these modes at 1203 and $1231 \mathrm{~cm}^{-1}$ are assigned to the $\mathrm{C}-\mathrm{O}$ stretching motion; in addition the peak at $1023 \mathrm{~cm}^{-1}$ is observed which corresponds to stretching of $\mathrm{C}-\mathrm{C}$ and $\mathrm{C}-\mathrm{O}$ bonds in vicinity of the new bond. Evidently the complex molecule IR spectrum does not have $\mathrm{O}-\mathrm{H}$ vibration mode as the hydroxyl group is removed through the esterification reaction.

\subsection{Electronic Spectra of the Species}

The electronic absorption spectra for lawsone, indoline D131 and the designed complex are computed both for vacuum and chloroform solution at the TD-DFT B3LYP5/6-31G(d,p); the PCM is used to account the solvent effect.

The vertical excitation energies, wavelengths, oscillator strengths and electronic configurations of the transitions are listed in Table 4 . The singlet-singlet excitations with nonzero oscillator strengths $(f>0.001)$ are taken into account. For the lawsone molecule the most probable transitions in vacuum are to the fifth and eighth excited states and attributed to $\mathrm{H}-4 \rightarrow \mathrm{L}$ and $\mathrm{H}-1 \rightarrow \mathrm{L}+1$, while in chloroform solution to the fifth and seventh excited states assigned to $\mathrm{H}-3 \rightarrow \mathrm{L}$ and $\mathrm{H} \rightarrow \mathrm{L}+1$ transitions. For the indoline both in vacuum and solution the highest oscillator strength is observed for the electron transition $\mathrm{H} \rightarrow \mathrm{L}$, to the first excited state. For the complex molecule the most probable transition occurs to the third excited state and assigned to $\mathrm{H} \rightarrow \mathrm{L}+1$ transition, both for vacuum and solution. Worth to note that in spectra of lawsone the band of the maximum absorption wavelength $\lambda_{\max }$ is in the ultraviolet region while for the D131 and designed complex molecule the values of $\lambda_{\max }$ correspond to visible region. Moreover for the complex, the additional peak is appeared at 655 (vacuum) and $814 \mathrm{~nm}$ (chloroform) but of low probability. From vacuum to chloroform solution, the red shift of $\lambda_{\max }$ is observed for all three species that is mostly common 
Table 4. The excitation energies $E_{\text {ex }}$, absorption wavelengths $\lambda$, oscillator strengths $f$ and electronic transition configurations of the individual dyes and designed complex molecule $\mathrm{C}_{45} \mathrm{H}_{32} \mathrm{~N}_{2} \mathrm{O}_{4}$ computed at the TD-DFT B3LYP5/6-31G(d,p).

\begin{tabular}{|c|c|c|c|c|}
\hline $\begin{array}{c}\text { Excited } \\
\text { State No. }\end{array}$ & $E_{\mathrm{ex}}, \mathrm{eV}$ & $\lambda, \mathrm{nm}$ & $f$ & $\begin{array}{l}\text { Electronic transition } \\
\text { configurations }\end{array}$ \\
\hline \multicolumn{5}{|c|}{ Lawsone in vacuum } \\
\hline 3 & 3.41 & 364 & 0.0030 & $\mathrm{H}-1 \rightarrow \mathrm{L}(90 \%)$ \\
\hline 4 & 3.79 & 328 & 0.0535 & $\mathrm{H}-2 \rightarrow \mathrm{L}(90 \%)$ \\
\hline 5 & 4.45 & 279 & 0.1790 & $\mathrm{H}-4 \rightarrow \mathrm{L}(86 \%)$ \\
\hline 8 & 5.40 & 230 & 0.1654 & $\mathrm{H}-1 \rightarrow \mathrm{L}+1(81 \%)$ \\
\hline 9 & 5.68 & 218 & 0.0026 & $\mathrm{H}-4 \rightarrow \mathrm{L}+1(67 \%)$ \\
\hline \multicolumn{5}{|c|}{ Lawsone in chloroform } \\
\hline 3 & 3.27 & 379 & 0.0026 & $\mathrm{H} \rightarrow \mathrm{L}(94 \%)$ \\
\hline 4 & 3.70 & 335 & 0.0566 & $\mathrm{H}-2 \rightarrow \mathrm{L}(94 \%)$ \\
\hline 5 & 4.38 & 283 & 0.1769 & $\mathrm{H}-3 \rightarrow \mathrm{L}(88 \%)$ \\
\hline 7 & 5.39 & 230 & 0.1916 & $\mathrm{H} \rightarrow \mathrm{L}+1(81 \%)$ \\
\hline 9 & 5.73 & 216 & 0.0012 & $\mathrm{H}-3 \rightarrow \mathrm{L}+1(66 \%)$ \\
\hline \multicolumn{5}{|c|}{ Indoline D131 in vacuum } \\
\hline 1 & 2.77 & 447 & 1.1836 & $\mathrm{H} \rightarrow \mathrm{L}(97 \%)$ \\
\hline 2 & 3.36 & 369 & 0.3336 & $\mathrm{H} \rightarrow \mathrm{L}+1(67 \%)$ \\
\hline 3 & 3.67 & 338 & 0.0483 & $\mathrm{H}-1 \rightarrow \mathrm{L}(67 \%)$ \\
\hline 4 & 4.03 & 308 & 0.0196 & $\mathrm{H} \rightarrow \mathrm{L}+2(71 \%)$ \\
\hline 5 & 4.13 & 300 & 0.0046 & $\mathrm{H} \rightarrow \mathrm{L}+3(58 \%)$ \\
\hline 6 & 4.18 & 297 & 0.1775 & $\mathrm{H}-1 \rightarrow \mathrm{H}+1(92 \%)$ \\
\hline 8 & 4.34 & 286 & 0.0222 & $\mathrm{H}-3 \rightarrow \mathrm{L}(64 \%)$ \\
\hline 9 & 4.35 & 285 & 0.0061 & $\mathrm{H} \rightarrow \mathrm{L}+4(34 \%)$ \\
\hline 10 & 4.39 & 282 & 0.0233 & $\mathrm{H}-6 \rightarrow \mathrm{L}(35 \%)$ \\
\hline \multicolumn{5}{|c|}{ Indoline D131 in chloroform } \\
\hline 1 & 2.60 & 476 & 0.9881 & $\mathrm{H} \rightarrow \mathrm{L}(99 \%)$ \\
\hline 2 & 3.28 & 378 & 0.5482 & $\mathrm{H}-1 \rightarrow \mathrm{L}(81 \%)$ \\
\hline 3 & 3.59 & 345 & 0.0859 & $\mathrm{H} \rightarrow \mathrm{L}+1(80 \%)$ \\
\hline 4 & 3.99 & 311 & 0.0061 & $\mathrm{H} \rightarrow \mathrm{L}+2(62 \%)$ \\
\hline 5 & 4.04 & 307 & 0.0122 & $\mathrm{H}-2 \rightarrow \mathrm{L}(67 \%)$ \\
\hline 6 & 44.11 & 302 & 0.0065 & $\mathrm{H}-3 \rightarrow \mathrm{L}(79 \%)$ \\
\hline 7 & 4.17 & 298 & 0.0051 & $\mathrm{H} \rightarrow \mathrm{L}+3(52 \%)$ \\
\hline 8 & 4.22 & 294 & 0.1268 & $\mathrm{H}-1 \rightarrow \mathrm{L}+1(90 \%)$ \\
\hline 9 & 4.24 & 293 & 0.0264 & $\mathrm{H} \rightarrow \mathrm{L}+2(48 \%)$ \\
\hline 10 & 4.25 & 291 & 0.0018 & $\mathrm{H}-4 \rightarrow \mathrm{L}(87 \%)$ \\
\hline
\end{tabular}




\section{Continued}

\begin{tabular}{ccccc}
\hline & \multicolumn{4}{c}{ Complex molecule in vacuum } \\
1 & 1.89 & 655 & 0.0086 & $\mathrm{H} \rightarrow \mathrm{L}(98 \%)$ \\
3 & 2.76 & 450 & 1.3178 & $\mathrm{H} \rightarrow \mathrm{L}+1(96 \%)$ \\
4 & 2.82 & 439 & 0.0019 & $\mathrm{H}-7 \rightarrow \mathrm{L}(85 \%)$ \\
6 & 3.34 & 371 & 0.3483 & $\mathrm{H} \rightarrow \mathrm{L}+2(58 \%)$ \\
7 & 3.48 & 356 & 0.0044 & $\mathrm{H}-9 \rightarrow \mathrm{L}(53 \%)$ \\
9 & 3.62 & 342 & 0.0860 & $\mathrm{H}-1 \rightarrow \mathrm{L}+1(55 \%)$ \\
& & Complex molecule in chloroform & \\
1 & 1.52 & 814 & 0.0081 & $\mathrm{H} \rightarrow \mathrm{L}(98 \%)$ \\
2 & 2.27 & 546 & 0.0014 & $\mathrm{H}-1 \rightarrow \mathrm{L}(98 \%)$ \\
3 & 2.54 & 488 & 1.0411 & $\mathrm{H} \rightarrow \mathrm{L}+1(98 \%)$ \\
8 & 3.20 & 387 & 0.6508 & $\mathrm{H}-1 \rightarrow \mathrm{L}+1(79 \%)$ \\
10 & 3.36 & 369 & 0.0078 & $\mathrm{H}-9 \rightarrow \mathrm{L}(66 \%)$ \\
\hline
\end{tabular}

effect mentioned elsewhere e.g. [28] [39] [55].

The theoretical electronic absorption spectra are compared to experimental UV-Vis spectra of dyes in chloroform solution in Figures 3-5.

The theoretical UV-Vis spectra of lawsone (Figure 3(a) and Figure 3(b)) depict a red shift of maximum wavelength from 279 (vacuum) to $283 \mathrm{~nm}$ (chloroform). The experimental UV-Vis spectrum of lawsone in chloroform solution shows the highest absorbance band in UV region with absorption peak at 292 $\mathrm{nm}$ and lower absorbance band at $338 \mathrm{~nm}$. Thus both theoretical and experimental results are in accordance and indicate maximal peaks in UV region with slight differences in the peaks position.

In the theoretical UV-Vis spectrum of the indoline D131 dye, the peak of maximum wavelength and highest intensity is observed at 447 (vacuum) and $476 \mathrm{~nm}$ (chloroform) hence the red shift is seen from vacuum to solution. The experimental spectrum of the indoline solution (Figure 4(c)) has broad bands with maxima located at 294, 334, 354 and $450,488 \mathrm{~nm}$. Thus the experimental results are comparable with the theoretical and also show similarity with data reported in [51] [56].

In the theoretical UV-Vis spectrum of the designed complex molecule (Figure 5(a) and Figure 5(b)), the highest peak is at 450 (vacuum) and $488 \mathrm{~nm}$ (chloroform), thus the red shift is also seen. In the experimental spectrum of the mixture (Figure 5(c)), the absorption bands lie in the UV-Vis region with maximum absorption peak at $500 \mathrm{~nm}$. Two peaks in visible region (450 and $500 \mathrm{~nm}$ ) apparently correspond to those in spectrum of the individual indoline D131 dye (450 and $488 \mathrm{~nm}$ ) while other peaks correspond to both individual dyes. Generally despite the slight dissimilarities, both the peak intensities and wavelengths in the spectrum of the mixture refer to those of the individual dyes. 


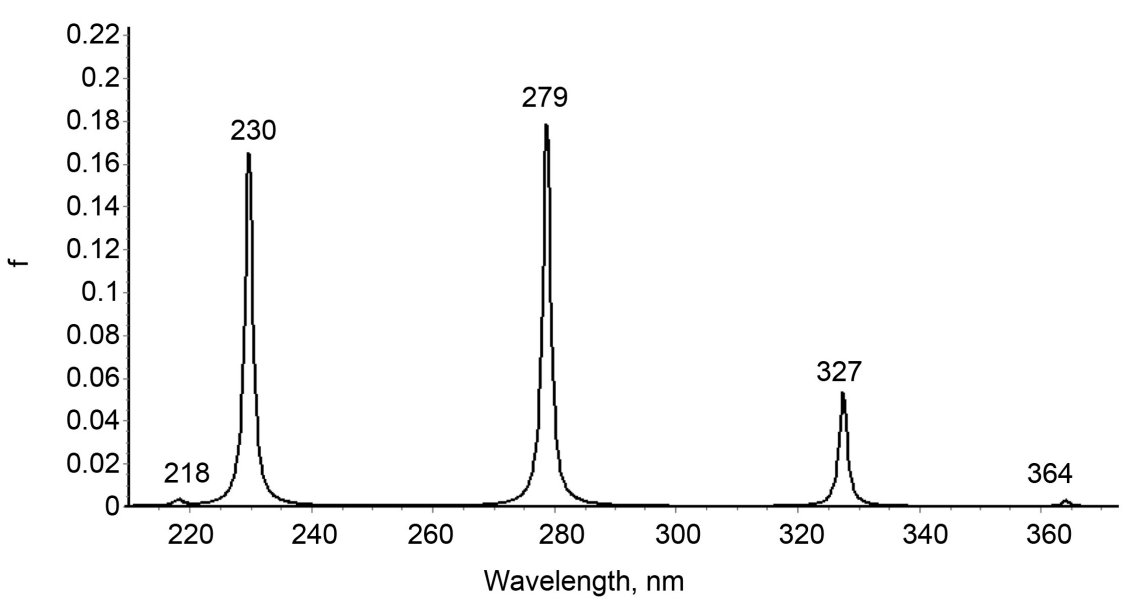

(a)

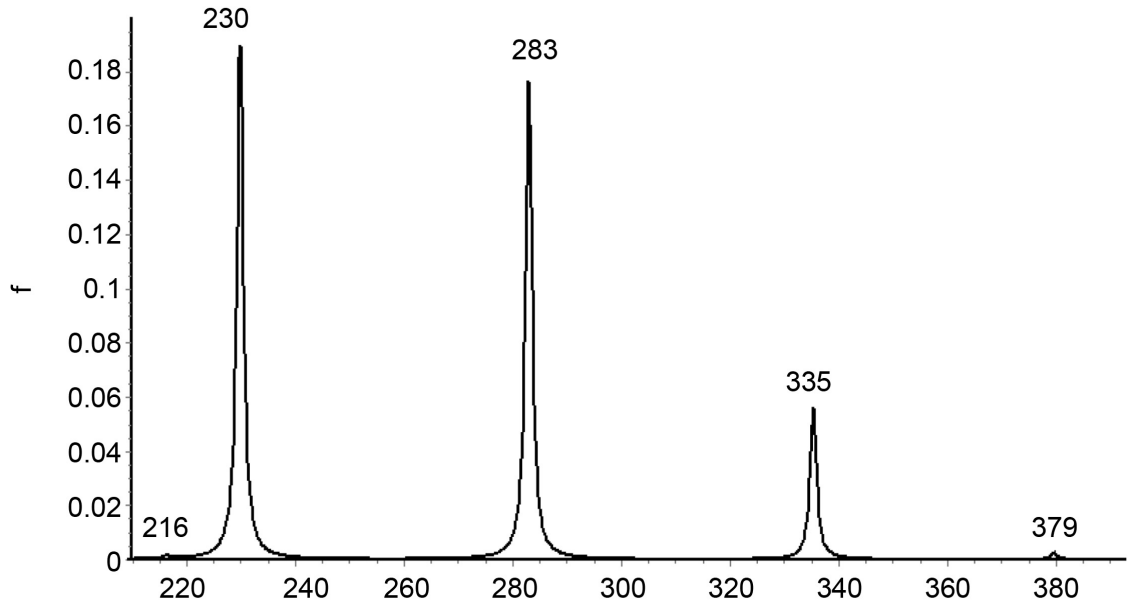

Wavelength, $\mathrm{nm}$

(b)

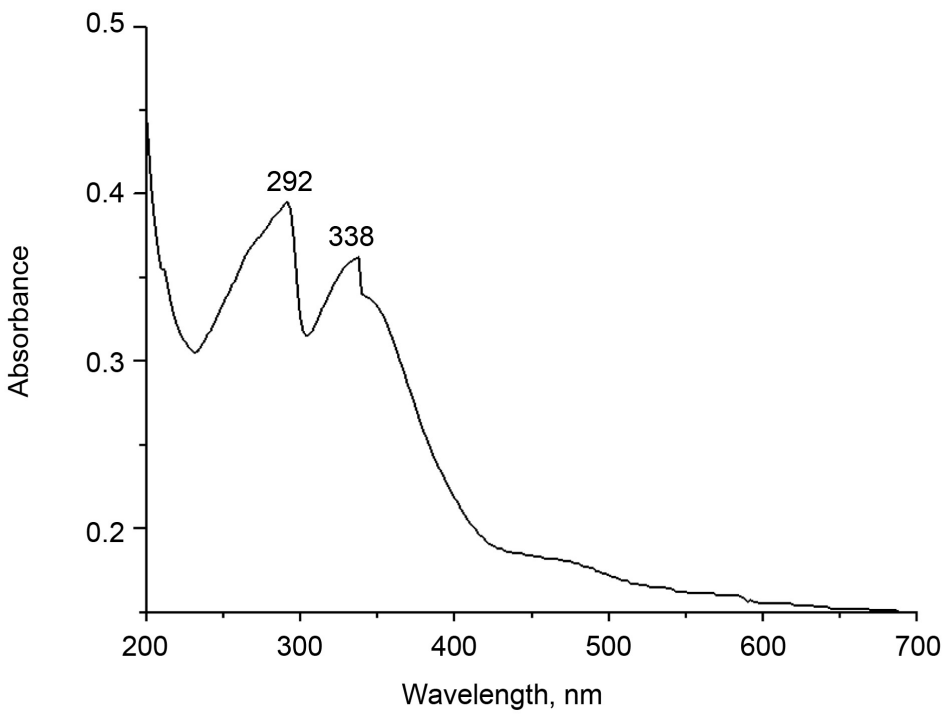

(c)

Figure 3. UV-Vis spectrum of lawsone: (a) computed for vacuum; (b) computed for chloroform solution; (c) experimental for chloroform solution. 


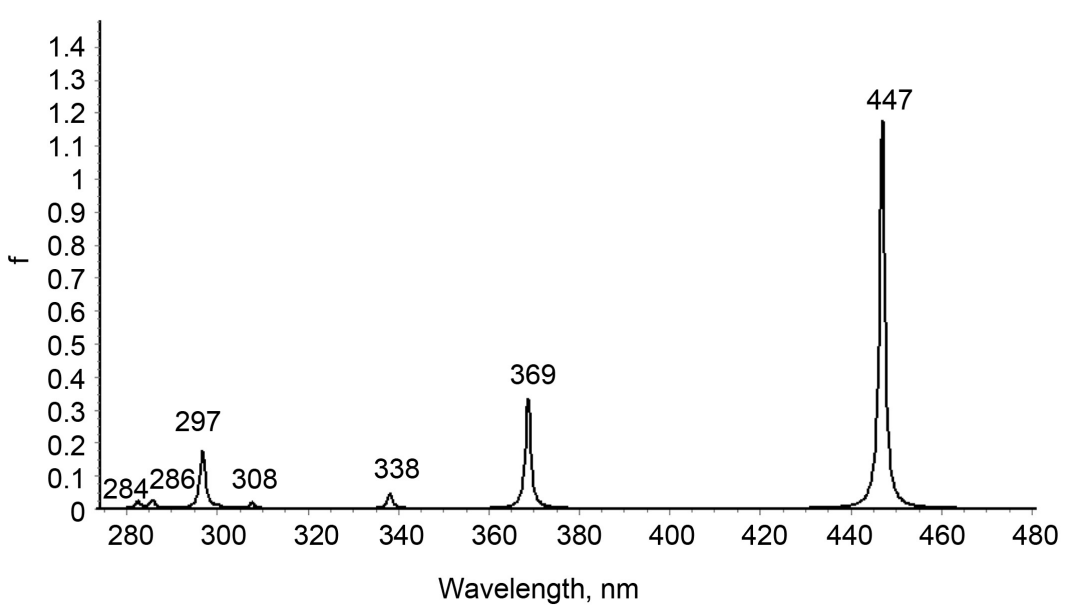

(a)

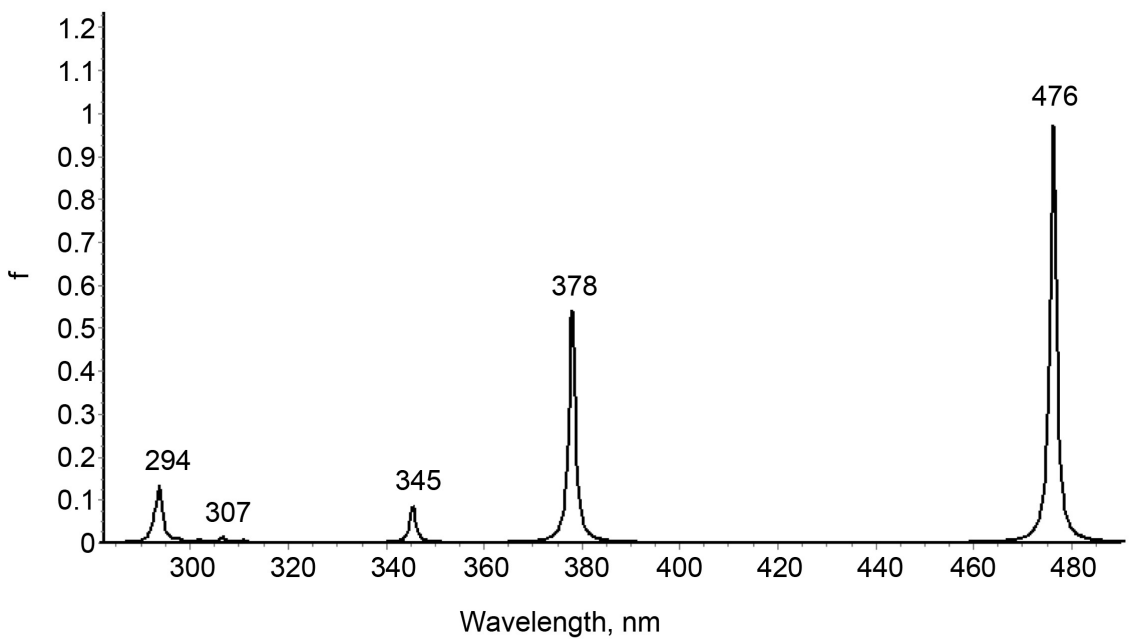

(b)

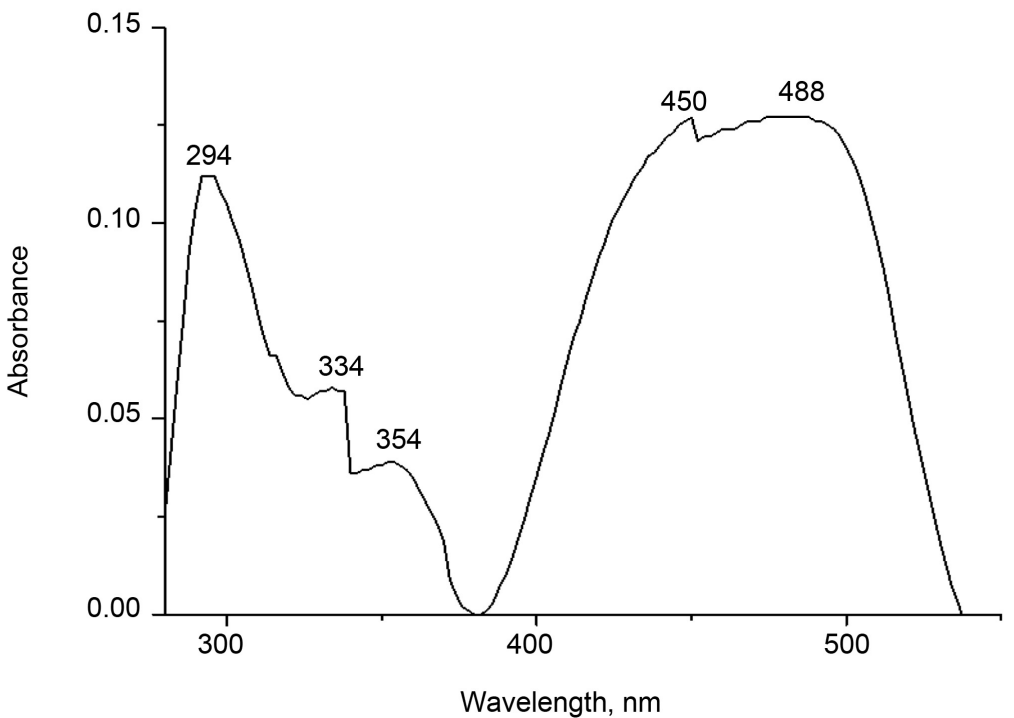

(c)

Figure 4. UV-Vis spectrum of indoline D131: (a) computed for vacuum; (b) computed for chloroform solution; (c) experimental for chloroform solution. 


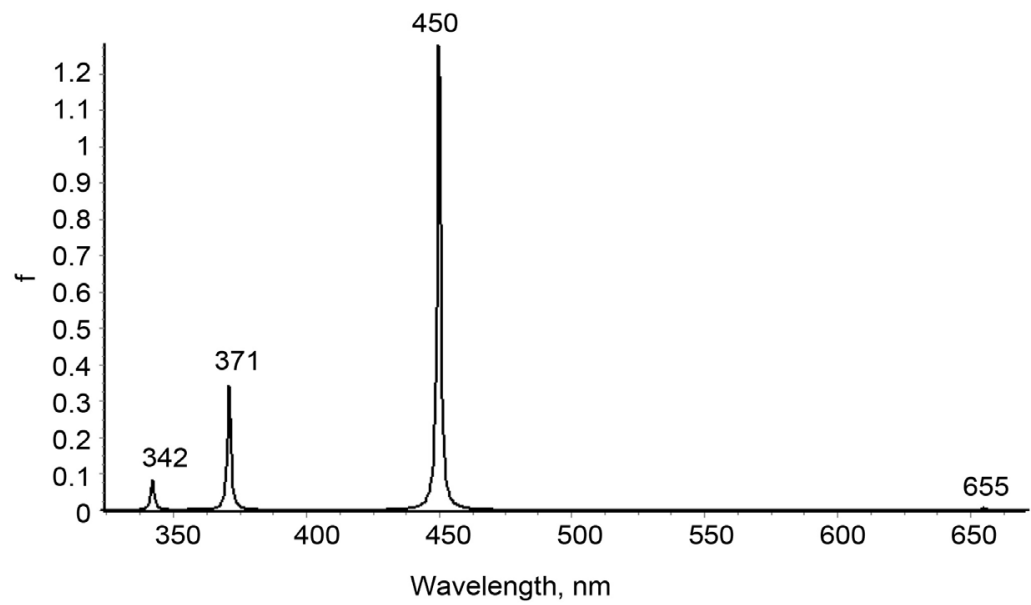

(a)

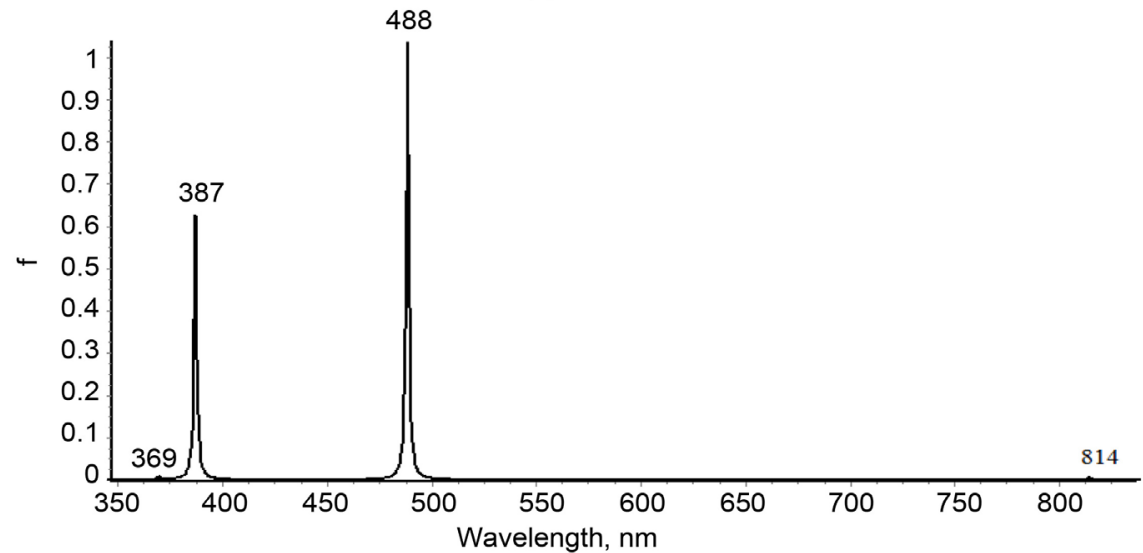

(b)

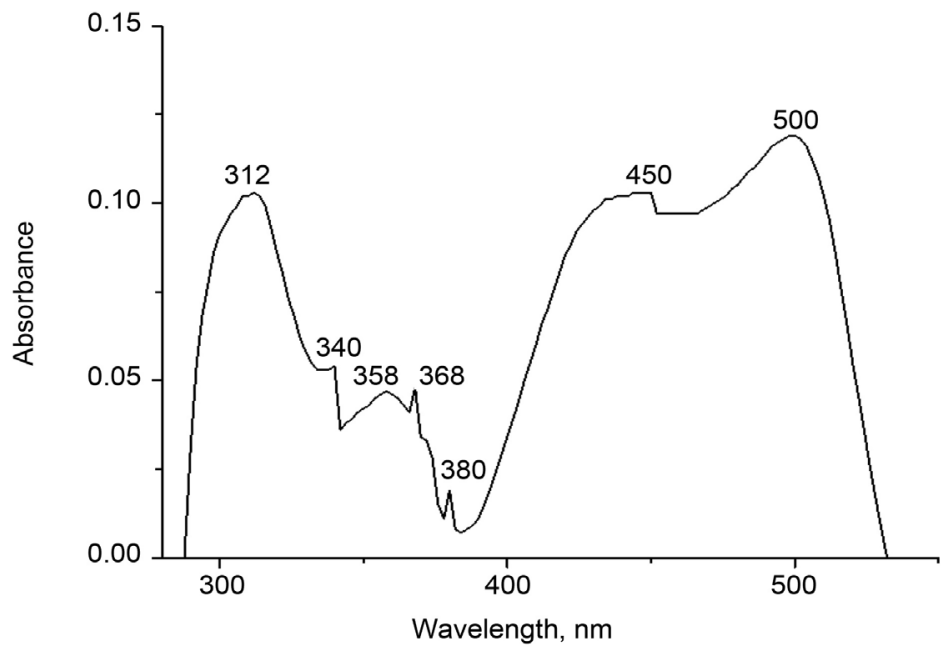

(c)

Figure 5. UV-Vis spectrum: (a) of complex molecule computed for vacuum; (b) of complex molecule computed for chloroform solution; (c) measured experimentally for the mixture of lawsone and indoline in chloroform solution.

\subsection{Analysis of Frontier Molecular Orbitals and Energy Levels Alignment}

Analysis of molecular orbitals can provide useful information on electronic 
structure of molecules and mechanisms of electron transitions and chemical reactions [57] [58] [59] [60]. However for understanding the mechanism of electron transitions the probabilities of the transitions must be taken into account, therefore the analysis of the whole electronic spectrum is required.

The frontier and adjacent molecular orbitals which mostly participate in the transitions are selected according to the data listed in Table 4 and shown in Figures 6-8 as computed for chloroform solution.

For the lawsone molecule, the shape of orbitals depicts that $\mathrm{H}-3$ and HOMO are delocalized over both rings, benzenoid and quinoid, whereas LUMO and L + 1 are centered mainly on the quinoid ring. This implies that $\pi \rightarrow \pi^{\star}$ transitions involve electron localization to the quinoid ring of lawsone.

In the D131, the shape of the HOMO indicates that the electron density is delocalized on the extended donor unit, while the LUMO is localized on the acceptor groups (cyanoacrylic acid). The HOMO $\rightarrow$ LUMO transition contributes mostly to the first excited state transition (Table 4). For the H-1 MO, electron density is delocalized over the entire molecule except the cyclopentane group.

For the designed complex molecule, the HOMO has the electron density only on the indoline part, mainly on the benzene rings, indole unit and cynoacrylic group adjacent to the linkage with lawsone. In the LUMO, the electron density is located mostly on the lawsone part with a small contribution from the linkage. In the $\mathrm{L}+1 \mathrm{MO}$, the electrons are concentrated on the indole unit and cynoacrylic part, while in both end parts and cyclopentane no any electron density is observed. The shape of the H-1 MO resembles that of HOMO since electrons are located in the indoline moiety and absent on the lawsone part.

In the most probabale transitions, $\mathrm{H} \rightarrow \mathrm{L}+1$ and $\mathrm{H}-1 \rightarrow \mathrm{L}+1$, the excitons formed are coupled via the new $\mathrm{C}-\mathrm{O}-\mathrm{C}$ bond between the indoline and lawsone moieties. Thus the excitons' size in the complex is enlarged compared to individual molecules. Therefore we suggest that recombination processes might be

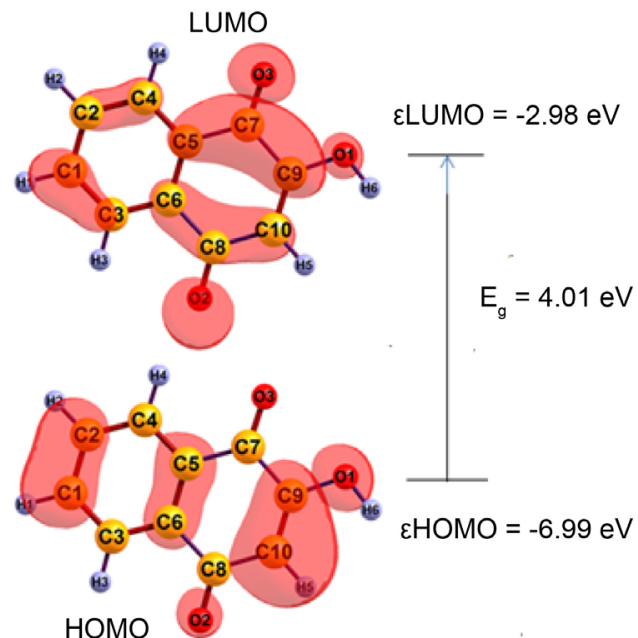

(a)

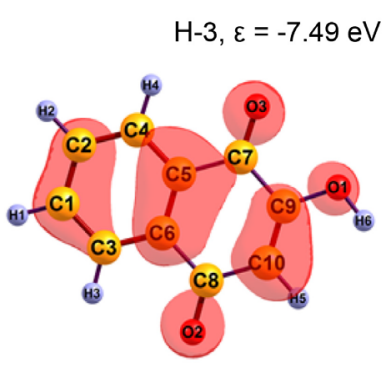

(b)
$\mathrm{L}+1, \varepsilon=-1.02 \mathrm{eV}$

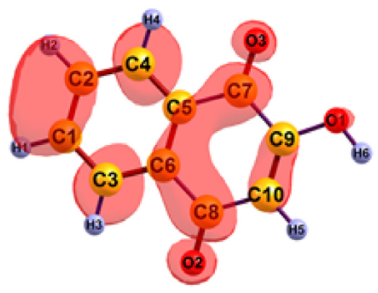

Figure 6. Frontier and adjacent MOs of lawsone molecule: (a) HOMO and LUMO; (b) H-3 MO; (c) L + 1 MO. 


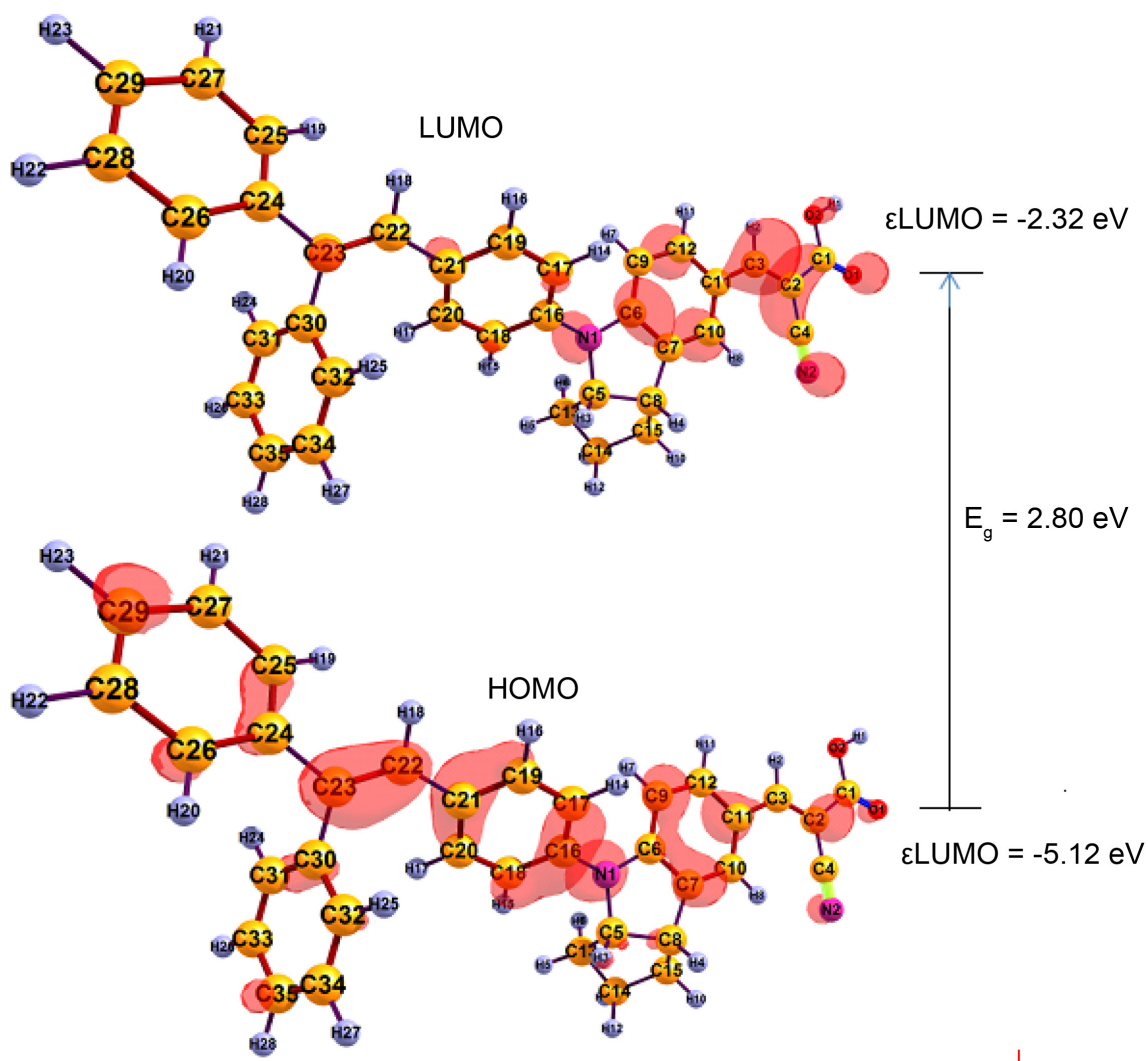

(a)

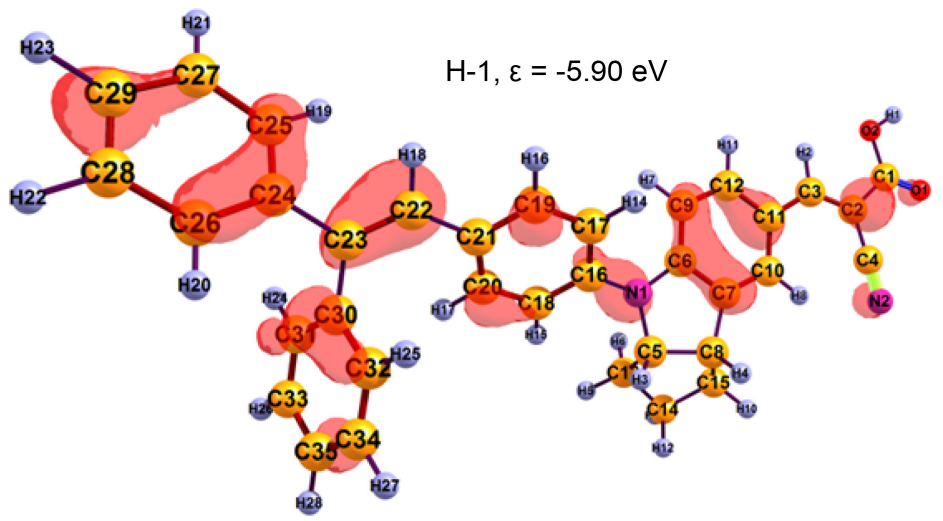

(b)

Figure 7. Frontier and adjacent MOs of indoline D131 molecule: (a) HOMO and LUMO; (b) H-3 MO.

hindered in the complex that in turn favours sensitizing efficiency of the dye.

Proper energy level alignment between semiconductor, sensitizer and electrolyte is among of the basic requirements for DSSCs [61] [62]. The simplest approach is to sketch the frontier MOs energy levels together with conduction and valence bands of a semiconductor and redox potential of electrolyte. Nevertheless more strict approach is to implement the excitation energies obtained by TD-DFT and calculate the excited state oxidation potentials (ESOPs) [62] [63] [64]. The values of ESOP were found as sum of the ground state occupied MOs energies and respective excitation energies, e.g. ESOP $=\varepsilon(\mathrm{HOMO})+E_{\mathrm{ex}}$. The 


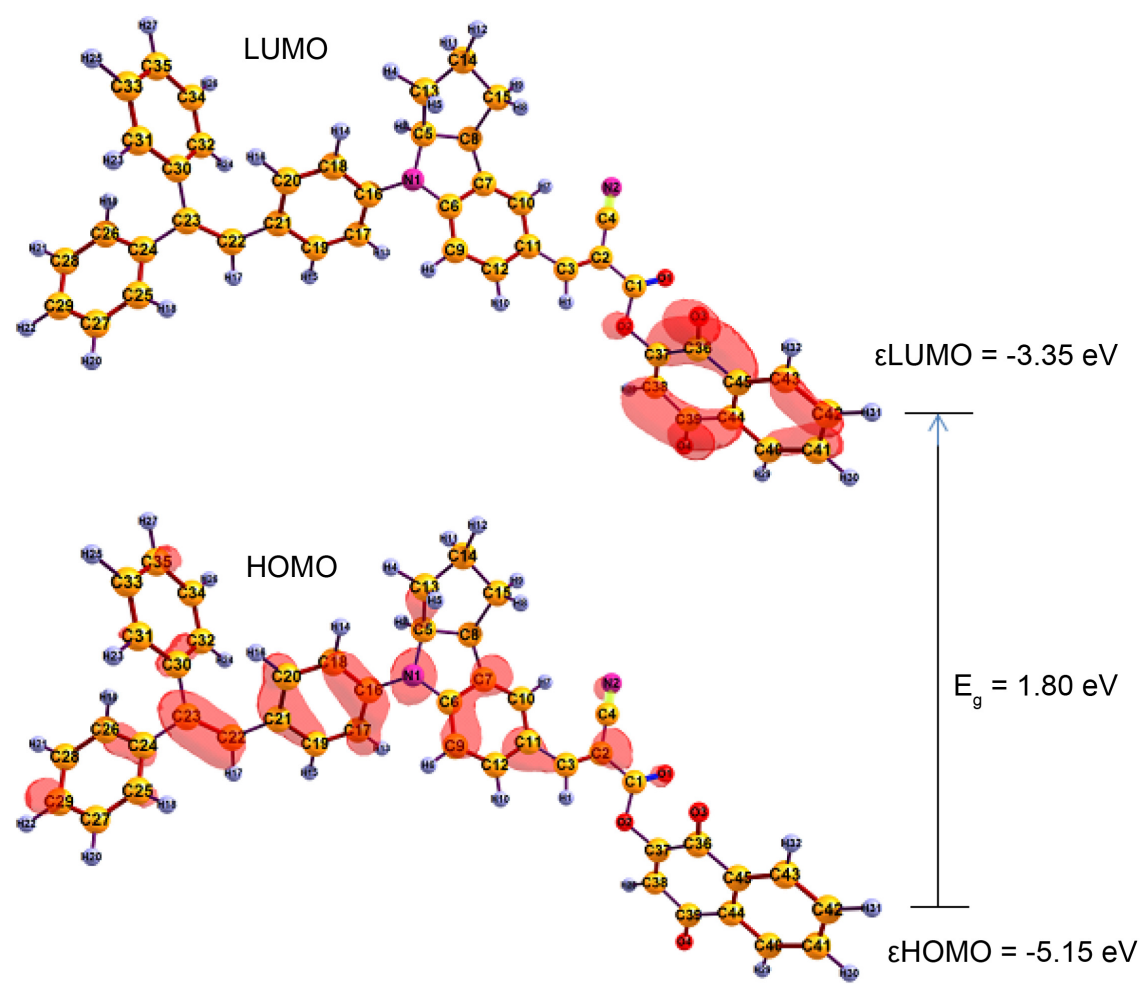

(a)

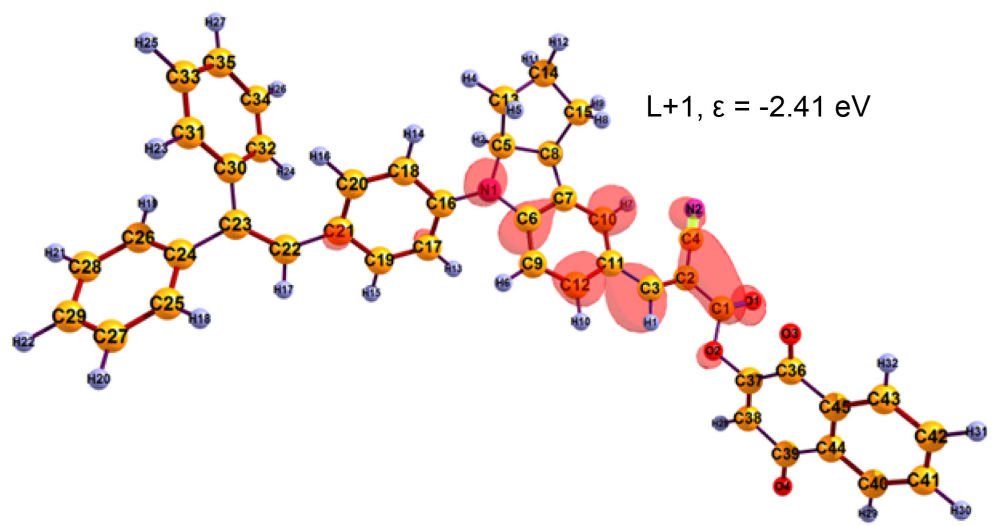

(b)

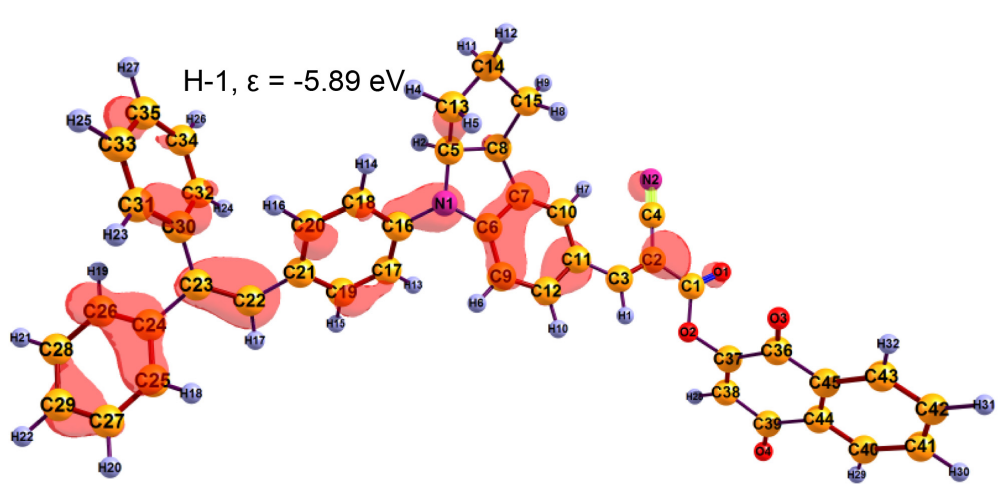

(c)

Figure 8. Frontier and adjacent MOs of complex molecule: (a) HOMO and LUMO; (b) L + $1 \mathrm{MO}$; (c) $\mathrm{H}-1 \mathrm{MO}$. 
calculated energies of frontier and adjacent MOs, excitation energies, energy gaps between relevant MOs and ESOPs are shown in Table 5. As is seen the energy gaps for each dye are systematically bigger compared to respective excitation energies; the maximum difference between $\mathrm{E}_{\mathrm{g}}$ and $\mathrm{E}_{\mathrm{ex}}$ is observed for lawsone dye, $0.60 \mathrm{eV}$ and $0.74 \mathrm{eV}$ for vacuum and chloroform solution, respectively. Thus the ESOPs are lower compared to respective unoccupied orbitals.

The energy levels of the relevant occupied MOs and ESOPs of the molecules under the study are shown in Figure 9; the results are compared with the valence and conduction bands of semiconductors $\mathrm{TiO}_{2}$ [63] [64] [65], $\mathrm{ZnO}$ [6] [65] and redox potential level of the electrolyte [66]. According to photosensitizer requirements, HOMO and LUMO levels of a dye must match conduction band (CB) of semiconductor and redox potential of electrolyte; the HOMO level of the

Table 5. The energies of molecular orbitals $\varepsilon(\mathrm{MO})$, excitation energies $E_{\mathrm{ex}}$, energy gaps $E_{\mathrm{g}}$, and excited state oxidation potentials ESOPs; all values in $\mathrm{eV}$.

\begin{tabular}{|c|c|c|c|c|c|c|}
\hline MO & $\varepsilon(\mathrm{MO})$ & Transition & $E_{\text {ex }}$ & $E_{\mathrm{g}}$ & $E_{\mathrm{g}}-E_{\text {ex }}$ & ESOP \\
\hline \multicolumn{7}{|c|}{ Lawsone dye in vacuum } \\
\hline $41, \mathrm{H}-4$ & -7.46 & $\mathrm{H}-4 \rightarrow \mathrm{L}$ & 4.45 & 4.58 & 0.13 & -3.01 \\
\hline $44, \mathrm{H}-1$ & -7.02 & $\mathrm{H}-1 \rightarrow \mathrm{L}+1$ & 5.40 & 6.00 & 0.60 & -1.62 \\
\hline $46, \mathrm{~L}$ & -2.88 & & & & & \\
\hline $47, \mathrm{~L}+1$ & -1.02 & & & & & \\
\hline \multicolumn{7}{|c|}{ Lawsone dye in chloroform } \\
\hline $42, \mathrm{H}-3$ & -7.49 & $\mathrm{H}-3 \rightarrow \mathrm{L}$ & 4.38 & 4.51 & 0.13 & -3.11 \\
\hline $45, \mathrm{H}$ & -6.99 & $\mathrm{H} \rightarrow \mathrm{L}$ & 3.27 & 4.01 & 0.74 & -3.72 \\
\hline $46, \mathrm{~L}$ & -2.98 & & & & & \\
\hline $47, L+1$ & -1.02 & $\mathrm{H} \rightarrow \mathrm{L}+1$ & 5.39 & 5.97 & 0.58 & -1.6 \\
\hline \multicolumn{7}{|c|}{ Indoline D131 in vacuum } \\
\hline $134, \mathrm{H}$ & -5.11 & $\mathrm{H} \rightarrow \mathrm{L}$ & 2.77 & 3.01 & 0.24 & -2.34 \\
\hline $135, \mathrm{~L}$ & -2.10 & & & & & \\
\hline \multicolumn{7}{|c|}{ Indoline D131 in chloroform } \\
\hline $133, \mathrm{H}-1$ & -5.90 & $\mathrm{H}-1 \rightarrow \mathrm{L}$ & 3.28 & 3.58 & 0.30 & -2.62 \\
\hline $134, \mathrm{H}$ & -5.12 & $\mathrm{H} \rightarrow \mathrm{L}$ & 2.60 & 2.80 & 0.20 & -2.52 \\
\hline $135, \mathrm{~L}$ & -2.32 & & & & & \\
\hline \multicolumn{7}{|c|}{ Complex molecule in vacuum } \\
\hline $174, \mathrm{H}$ & -5.18 & $\mathrm{H} \rightarrow \mathrm{L}$ & 1.89 & 2.2 & 0.31 & -3.29 \\
\hline $175, \mathrm{~L}$ & -2.98 & & & & & \\
\hline $176, \mathrm{~L}+1$ & -2.18 & $\mathrm{H} \rightarrow \mathrm{L}+1$ & 2.76 & 3.0 & 0.24 & -2.42 \\
\hline \multicolumn{7}{|c|}{ Complex molecule in chloroform } \\
\hline $173, \mathrm{H}-1$ & -5.89 & $\mathrm{H}-1 \rightarrow \mathrm{L}+1$ & 3.20 & 3.48 & 0.28 & -2.69 \\
\hline $174, \mathrm{H}$ & -5.15 & $\mathrm{H} \rightarrow \mathrm{L}$ & 1.52 & 1.7 & 0.18 & -3.63 \\
\hline $175, \mathrm{~L}$ & -3.45 & & & & & \\
\hline $176, \mathrm{~L}+1$ & -2.41 & $\mathrm{H} \rightarrow \mathrm{L}+1$ & 2.54 & 2.74 & 0.20 & -2.61 \\
\hline
\end{tabular}




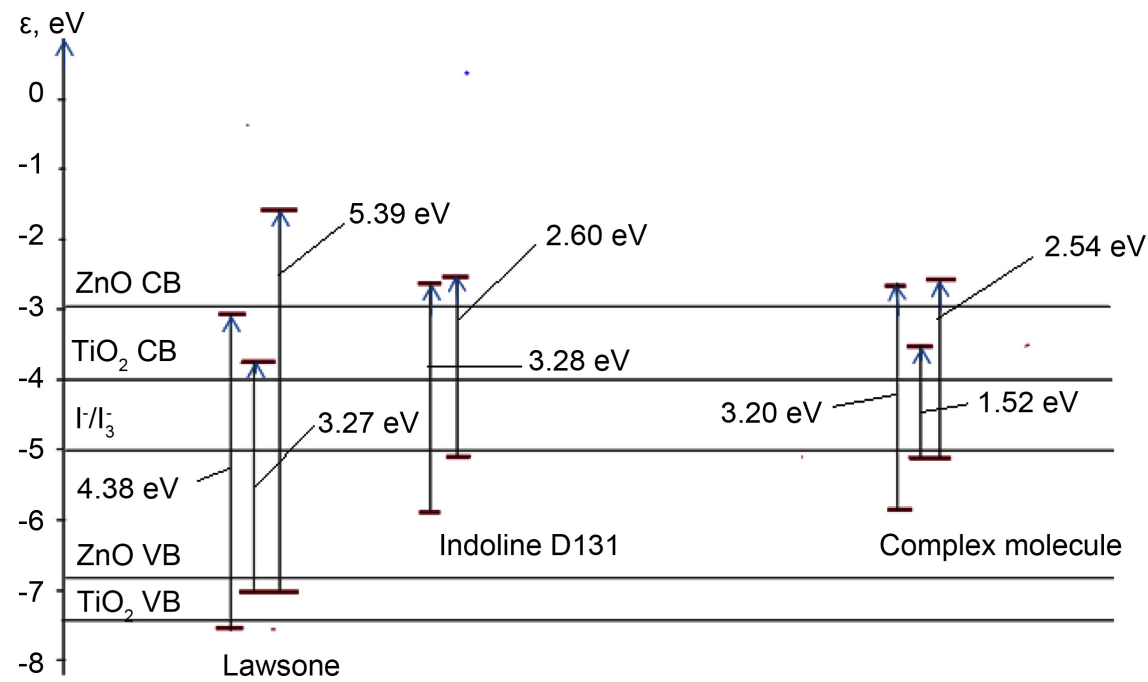

Figure 9. Energy level diagram of the relevant occupied MOs, transition energies and ESOPs of lawsone, indoline D131 and designed complex molecule computed for chloroform solution. The conduction and valence bands of $\mathrm{TiO}_{2}$ [63] [64] [65] and $\mathrm{ZnO}$ [6] [65] semiconductors and redox potential of the electrolyte $\mathrm{I}^{-} / \mathrm{I}_{3}^{-} \quad[66]$ are given for comparison.

sensitizer has to be lower than the redox potential for efficient dye regeneration, while the LUMO must be slightly higher than the $\mathrm{CB}$ edge so that the electron injection to semiconductor is energetically favorable [67].

In our case instead of LUMO we consider the ESOP energy levels (Figure 9). The HOMO and H-1 levels of lawsone are far below the redox potential of the electrolyte, whereas the ESOPs are above the $\mathrm{CB}$ edge of $\mathrm{TiO}_{2}$ but only ESOP = $-1.6 \mathrm{eV}$ is above the $\mathrm{CB}$ of $\mathrm{ZnO}$. The HOMO and $\mathrm{H}-1$ levels of the indoline and designed molecule are below the electrolyte redox potential, while the ESOPs are above the $\mathrm{CB}$ edges of both semiconductors. Therefore regarding the proper energy levels alignment, the designed complex, lawsone and indoline satisfy the requirement to be used as a photosensitizer for $\mathrm{TiO}_{2}$ or $\mathrm{ZnO}$ semiconductors. The designed complex is predicted to be better sensitizer as it possesses smaller excitation energies (3.20, 1.52 and $2.54 \mathrm{eV}$ ) compared to the indoline (3.28 and $2.60 \mathrm{eV})$ and lawsone $(4.38,3.27$ and $5.39 \mathrm{eV})$. Furthermore, the transition from $\mathrm{HOMO}$ to the first excited state favours sensitization of $\mathrm{TiO}_{2}$ as the respective ESOP $=-3.63 \mathrm{eV}$ is close to the $\mathrm{CB}$ edge $(-4.0 \mathrm{eV})$. The transitions from $\mathrm{H}-1$ and from HOMO to the second excited state are of high probability to be involved in sensitizing the $\mathrm{ZnO}$ semiconductor, as the two corresponding ESOP levels $(-2.69$ and $-2.61 \mathrm{eV})$ are slightly above the $\mathrm{CB}$ of $\mathrm{ZnO}(-2.96 \mathrm{eV})$.

\section{Conclusion}

The complex molecule was theoretically designed via combination of natural lawsone dye and synthetic metal free indoline D131 dye. The equilibrium geometry structures, electronic and IR spectra of the individual dyes and complex molecule were computed using DFT and TD-DFT methods; also the UV-Vis 
spectra of the individual dyes' solutions and their mixture were measured and analyzed. In the complex molecule, the formation of the link $\mathrm{C}-\mathrm{O}-\mathrm{C}$ between the lawsone and indoline moieties is accompanied with slight change of the geometrical parameters of the moieties, but clearly exhibited in the IR spectrum of the complex as the most intensive peaks originate from the new formed bond. Based on thermodynamic approach, the complex formation reaction is found to be endothermic and non-spontaneous. Compared to the individual dyes, in the theoretical optical spectrum of the designed molecule the highest peaks are red shifted. As for the experimental UV-Vis spectrum of the mixture, both the peak intensities and wavelengths, in general refer to those of the individual dyes. The electron density distribution over frontier and adjacent MOs and most probable electronic transitions have been scrutinized. The electron excitations in the complex bring to lager size of the excitons that might hinder electron-hole recombination. Also the complex possesses better energy level alignment with the conduction band of the $\mathrm{TiO}_{2}$ and $\mathrm{ZnO}$ semiconductors and redox level of the $\mathrm{I}^{-} / \mathrm{I}_{3}^{-}$electrolyte. Therefore we suggest the designed complex is a promising sensitizer for efficient DSSCs with better PCE compared to that of the individual dyes.

\section{Conflicts of Interest}

The authors declare no conflicts of interest regarding the publication of this paper.

\section{References}

[1] Urbani, M., Grätzel, M., Nazeeruddin, M.K. and Torres, T. (2014) Meso-Substituted Porphyrins for Dye-Sensitized Solar Cells. American Chemical Society, 114, 12330-12396.

[2] Brédas, J.-L., Norton, J. E., Cornil, J. and Coropceanu, V. (2009) Molecular Understanding of Organic Solar Cells: The Challenges. Accounts of Chemical Research, 42, 1691-1699.

[3] Yuan, H., Wang, W., Xu, D., Xu, Q., Xie, J., Chen, X., Zhang, T., Xiong, C., He, Y., Zhang, Y., Liu, Y. and Shen, H. (2018) Outdoor Testing and Ageing of Dye-Sensitized Solar Cells for Building Integrated Photovoltaics. Solar Energy, 165, 233-239.

[4] O’Regan, B. and Grätzel, M. (1991) A Low-Cost, High-Efficiency Solar Cell Based on Dye-Sensitized Colloidal $\mathrm{TiO}_{2}$ Films. Nature, 353, 737-740.

[5] Kanaparthi, R.K., Kandhadi, J. and Giribabu, L. (2012) Metal-Free Organic Dyes for Dye-Sensitized Solar Cells: Recent Advances. Tetrahedron, 68, 8383-8393.

[6] Jose, R., Thavasi, V. and Ramakrishna, S. (2009) Metal Oxides for Dye-Sensitized Solar Cells. Journal of the American Ceramic Society, 92, 289-301.

[7] Grätzel, M. (2001) Photoelectrochemical Cells. Nature, 414, 338-344.

[8] Dongre, J. (2017) A Comparative Study on the CDS Sensitized and Dye-Sensitized $\mathrm{ZnO}$ Photoelectrodes Based on Solar Cell Performance. International Journal of Applied Research, 3, 504-507.

[9] Abdalla, J., Huang, Y.-W., Yu, Q.-J., Wang, J.-Z., Wang, J.-N., Yu, C.-L., Gao, S.-Y., 
Jiao, S.-J., Wang, D.-B. and Alarabi, A. (2017) $\mathrm{TiCl}_{4}$ Surface-Treated $\mathrm{SnO}_{2}$ Photoanodes for Self-Powered UV Photodetectors and Dye-Sensitized Solar Cells. Materials Technology, 32, 443-450.

[10] Arbab, A.A., Peerzada, M.H., Sahito, I.A. and Jeong, S.H. (2017) A Complete Carbon Counter Electrode for high Performance Quasi Solid State Dye Sensitized Solar Cell. Journal of Power Sources, 343, 412-423.

[11] Narayan, M.R. (2011) Review: Dye Sensitized Solar Cells Based on Natural Photosensitizers. Elsevier, 16, 208-215.

[12] Nishio, Y., Yamaguchi, T., Yamguchi, T., Nishio, K. and Hayase, S. (2016) Transparent Conductive Oxide-Less Dye-Sensitized Solar Cells (TCO-Less DSSC) with Titanium Nitride Compact Layer on Back Contact Ti Metal Mesh. Journal of Applied Electrochemistry, 46, 551-557.

[13] Shalini, S., Balasundaraprabhu, R., Kumar, T.S., Prabavathy, N., Senthilarasu, S. and Prasanna, S. (2016) Status and Outlook of Sensitizers/Dyes Used in Dye Sensitized Solar Cells (DSSC): A Review. International Journal of Energy Research, 40, 1303-1320.

[14] Arakawa, H., Yamaguchi, T., Okada, K., Matsui, H., Kitamura, T. and Tanabe, N. (2009) Highly Durable Dye-Sensitized Solar Cells. Fujikura Technical Review, 55-59.

[15] Li, B., Wang, L., Kang, B., Wang, P. and Qiu, Y. (2006) Review of Recent Progress in Solid-State Dye-Sensitized Solar Cells. Solar Energy Materials and Solar Cells, 90, 549-573.

[16] Lee, C.W., Lu, H.P., Lan, C.M., Huang, Y.L., Liang, Y.R., Yen, W.N., Liu, Y.C., Lin, Y.S., Diau, E.W.G. and Yeh, C.Y. (2009) Novel Zinc Porphyrin Sensitizers for Dye-Sensitized Solar Cells: Synthesis and Spectral, Electrochemical, and Photovoltaic Properties. Chemistry-A European Journal, 15, 1403-1412. https://doi.org/10.1002/chem.200801572

[17] Hara, K., Sato, T., Katoh, R., Furube, A., Ohga, Y., Shinpo, A., Suga, S., Sayama, K., Sugihara, H. and Arakawa, H. (2003) Molecular Design of Coumarin Dyes for Efficient Dye-Sensitized Solar Cells. The Journal of Physical Chemistry B, 107, 597-606. https://doi.org/10.1021/jp026963x

[18] Santhanamoorthi, N., Lo, C.-M. and Jiang, J.-C. (2013) Molecular Design of Porphyrins for Dye-Sensitized Solar Cells: A DFT/TDDFT Study. The Journal of Physical Chemistry Letters, 4, 524-530. https://pubs.acs.org/doi/abs/10.1021/jz302101j https://doi.org/10.1021/jz302101j

[19] Wu, Y., Marszalek, M., Zakeeruddin, S.M., Zhang, Q., Tian, H., Grätzel, M. and Zhu, W. (2012) High-Conversion-Efficiency Organic Dye-Sensitized Solar Cells: Molecular Engineering on D-A- $\pi$-A Featured Organic Indoline Dyes. Energy \& Environmental Science, 5, 8261-8272. https://doi.org/10.1039/c2ee22108j

[20] Alhamed, M., Issa, A.S. and Doubal, A.W. (2012) Studying of Natural Dyes Properties as Photo-Sensitizer for Dye Sensitized Solar Cells (DSSC). Journal of Electron Devices, 16, 1370-1383.

[21] Wongcharee, K., Meeyoo, V. and Chavadej, S. (2007) Dye-Sensitized Solar Cell Using Natural Dyes Extracted from Rosella and Blue Pea Flowers. Solar Energy Materials and Solar Cells, 91, 566-571. https://doi.org/10.1016/j.solmat.2006.11.005

[22] Chang, H., Wu, H., Chen, T., Huang, K., Jwo, C. and Lo, Y. (2010) Dye-Sensitized Solar Cell Using Natural Dyes Extracted from Spinach and Ipomoea. Journal of Alloys and Compounds, 495, 606-610. https://doi.org/10.1016/j.jallcom.2009.10.057

[23] Chiba, Y., Islam, A., Watanabe, Y., Komiya, R., Koide, N. and Han, L. (2006) 
Dye-Sensitized Solar Cells with Conversion Efficiency of $11.1 \%$. Japanese Journal of Applied Physics, 45, L638-L640. https://doi.org/10.1143/JJAP.45.L638

[24] Nazeeruddin, M.K., Baranoff, E. and Grätzel, M. (2011) Dye-Sensitized Solar Cells: A Brief Overview. Solar Energy, 85, 1172-1178. https://doi.org/10.1016/j.solener.2011.01.018

[25] Hagfeldt, A., Boschloo, G., Sun, L., Kloo, L. and Pettersson, H. (2010) Dye-Sensitized Solar Cells. Chemical Reviews-American Chemical Society, 110, 6595-6663. https://doi.org/10.1021/cr900356p

[26] Mathew, S., Yella, A., Gao, P., Humphry-Baker, R., Curchod, B.F., Ashari-Astani, N., Tavernelli, I., Rothlisberger, U., Nazeeruddin, M.K. and Gratzel, M. (2014) Dye-Sensitized Solar Cells with 13\% Efficiency Achieved through the Molecular Engineering of Porphyrin Sensitizers. Nature Chemistry, 6, 242-247. https://doi.org/10.1038/nchem.1861

[27] Xu, J., Zhang, H., Liang, G., Wang, L., Weilin, X., Cui, W. and Zengchang, L. (2010) DFT Studies on the Electronic Structures of Indoline Dyes for Dye-Sensitized Solar Cells. Journal of the Serbian Chemical Society, 75, 259-269. https://doi.org/10.2298/JSC1002259X

[28] Han, M.W., Ekanayake, P., Ming, L.C. and Yoong, V.N. (2015) DFT/TD-DFT Studies on the Lawsone (Henna) as a Photosensitizer for Dye-Sensitized Solar Cells. Applied Mechanics and Materials, 789-790, 56-60.

[29] Sun, C., Li, Y., Song, P. and Ma, F. (2016) An Experimental and Theoretical Investigation of the Electronic Structures and Photoelectrical Properties of Ethyl Red and Carminic Acid for DSSC Application. Materials, 9, 1-22. https://doi.org/10.3390/ma9100813

[30] Le Bahers, T., Pauporté, T., Scalmani, G., Adamo, C. and Ciofini, I. (2009) A TD-DFT Investigation of Ground and Excited State Properties in Indoline Dyes Used for Dye-Sensitized Solar Cells. Physical Chemistry Chemical Physics, 11, 11276-11284. https://doi.org/10.1039/b914626a

[31] Keerthi, A., Chua, M.H., Timothy Chan, T.Y., Liu, Y., Wang, Q. and Valiyaveettil, S. (2016) Synthesis of Multi-Donor Dyes and Influence of Molecular Design on Dye-Sensitized Solar Cells. The Royal Society of Chemistry, 6, 51807-51815. https://doi.org/10.1039/C6RA08530J

[32] Ren, P., Zhang, Y., Luo, Z., Song, P. and Li, Y. (2017) Theoretical and Experimental Study on Spectra, Electronic Structure and Photoelectric Properties of Three Nature Dyes Used for Solar Cells. Journal of Molecular Liquids, 247, 193-206. https://doi.org/10.1016/j.molliq.2017.09.088

[33] El-Shishtawy, R.M. (2009) Functional Dyes, and Some Hi-Tech Applications. International Journal of Photoenergy, 2009, Article ID: 434897.

[34] Kim, B.G., Chung, K. and Kim, J. (2013) Molecular Design Principle of All-Organic Dyes for Dye-Sensitized Solar Cells. Chemistry, 19, 5220-5230. https://doi.org/10.1002/chem.201204343

[35] Morita, S., Ikegami, M., Wei, T.C. and Miyasaka, T. (2014) Quantum Conversion Enhancement with $\mathrm{TiO}_{\mathrm{x}}$ Compact Layers for ITO-Plastic-Film-Based Low-Temperature-Processed Dye-Sensitized Photoelectrodes. European Journal of Chemical Physics and Physical Chemistry, 15, 1190-1193. https://doi.org/10.1002/cphc.201301061

[36] Shibayama, N., Inoue, Y., Abe, M., Kajiyama, S., Ozawa, H., Miura, H. and Arakawa, H. (2015) Novel Near-Infrared Carboxylated 1, 3-Indandione Sensitizers for Highly Efficient Flexible Dye-Sensitized Solar Cells. Chemical Communications, 51, 
12795-12798. https://doi.org/10.1039/C5CC03049H

[37] Sun, X., Wang, Y., Li, X., Agren, H., Zhu, W., Tian, H. and Xie, Y. (2014) Cosensitizers for Simultaneous Filling up of both Absorption Valleys of Porphyrins: A Novel Approach for Developing Efficient Panchromatic Dye-Sensitized Solar Cells. The Royal Society of Chemistry, 50, 1-4.

[38] Msangi, A., Pogrebnoi, A. and Pogrebnaya, T. (2018) Combination of Natural Dye (Crocetin) and Synthetic Dye (Indoline D205) for DSSCs Application. International Journal of Computational and Theoretical Chemistry, 6, 1-13.

[39] Sharma, G.D., Angaridis, P.A., Pipou, S., Zervaki, G.E., Nikolaou, V., Misra, R. and Coutsolelos, A.G. (2015) Efficient Co-Sensitization of Dye-Sensitized Solar Cells by Novel Porphyrin/Triazine Dye and Tertiary Aryl-Amine Organic Dye. Elsevier, 25, 295-307.

[40] Nguyen, L.H., Mulmudi, H.K., Sabba, D., Kulkarni, S.A., Batabyal, S.K., Nonomura, K., Gratzel, M. and Mhaisalkar, S.G. (2012) A Selective Co-Sensitization Approach to Increase Photon Conversion Efficiency and Electron Lifetime in Dye-Sensitized Solar Cells. Physical Chemistry Chemical Physics, 14, 16182-16186. https://doi.org/10.1039/c2cp42959d

[41] Xie, Y., Wu, L., Han, L. and Gao, J. (2017) Co-Sensitization by Triarylamine Dyes for Improved Dye-Sensitized Solar Cells. Physical Status Solidi Applications and Materials Science, 214, 1-6. https://doi.org/10.1002/pssa.201600938

[42] Pamain, A., Pogrebnaya, T. and King'ondu, C.K. (2014) Natural Dyes for Solar Cell Application: UV-Visible Spectra and Outdoor Photovoltaic Performance. Research Journal in Engineering and Applied Sciences, 3, 332-336.

[43] http://www.chemspider.com

[44] Lemmon, E., McLinden, M., Friend, D., Linstrom, P. and Mallard, W. (2011) NIST Chemistry WebBook, Nist Standard Reference Database Number 69. National Institute of Standards and Technology, Gaithersburg. https://webbook.nist.gov/chemistry/

[45] Tokarev, K. (2007-2009) OpenThermo v. 1.0 Beta 1 (C).

[46] Granovsky, A.A. (1994-2018) Firefly Version 8.8. http://classic.chem.msu.su/gran/gamess/index.html

[47] Schmidt, M.W., Baldridge, K.K., Boatz, J.A., Elbert, S.T., Gordon, M.S., Jensen, J.H., Koseki, S., Matsunaga, N., Nguyen, K.A. and Su, S. (1993) General Atomic and Molecular Electronic Structure System. Journal of Computational Chemistry, 14, 1347-1363. https://doi.org/10.1002/jcc.540141112

[48] Zhurko, G. and Zhurko, D. (2015) Chemcraft Graphical Program for Visualization of Computed Results. http://www.chemcraftprog.com/

[49] Bode, B.M. and Gordon, M.S. (1998) MacMolPlt: A Graphical User Interface for GAMESS. Journal of Molecular Graphics and Modelling, 16, 133-138. https://doi.org/10.1016/S1093-3263(99)00002-9

[50] Mahkam, M., Kafshboran, H.R. and Nabati, M. (2014) Synthesis and Characterization of Novel Colored Polymers Based on Lawsone Natural Compound. Designed Monomers and Polymers, 17, 784-794. https://doi.org/10.1080/15685551.2014.918017

[51] Dentani, T., Kubota, Y., Funabiki, K., Jin, J., Yoshida, T., Minoura, H., Miura, H. and Matsui, M. (2009) Novel Thiophene-Conjugated Indoline Dyes for Zinc Oxide Solar Cells. New Journal of Chemistry, 33, 93-101. https://doi.org/10.1039/B808959K 
[52] Allen, F.H. and Kirby, A.J. (1984) Bond Length and Reactivity. Variable Length of the Carbon-Oxygen Single Bond. Journal of the American Chemical Society, 106, 6197-6200. https://doi.org/10.1021/ja00333a013

[53] Sutton, L.E. (1965) Tables of Interatomic Distances and Configuration in Molecules and Ions (Supplement 1956-1959). Chemical Society.

[54] Hrmova, M., Varghese, J.N., De Gori, R., Smith, B.J., Driguez, H. and Fincher, G.B. (2001) Catalytic Mechanisms and Reaction Intermediates along the Hydrolytic Pathway of a Plant $\beta$-D-Glucan Glucohydrolase. Structure, 9, 1005-1016. https://doi.org/10.1016/S0969-2126(01)00673-6

[55] Makuraza, J., Pogrebnaya, T. and Pogrebnoi, A. (2015) Vibrational and Electronic Spectra of Natural Dyes Constituents for Solar Cell Application: DFT and TDDFT Study. International Journal of Materials Science and Applications, 4, 314-324. https://doi.org/10.11648/j.ijmsa.20150405.16

[56] Liu, Z., Wang, X.-F., Wang, Z., Ojima, H., Hong, Z., Tian, W. and Kido, J. (2013) Indoline-Based Donor Molecule for Efficient Co-Evaporated Organic Photovoltaics. Organic Electronics, 14, 2210-2215. https://doi.org/10.1016/j.orgel.2013.05.029

[57] Lin, H., Zhu, S.-G., Chen, P.-Y., Li, K., Li, H.-Z. and Peng, X.-H. (2013) DFT Investigation of a High Energy Density Polynitro Compound, 2,2'-Bis(trinitromethyl)5,5'-azo-1,2,3,4-tetrazole. Central European Journal of Energetic Materials, 10, 325-338.

[58] Wu, C.J., Yang, L.H., Fried, L.E., Quenneville, J. and Martinez, T.J. (2003) Electronic Structure of Solid 1,3,5-triamino-2,4,6-trinitrobenzene under Uniaxial Compression: Possible Role of Pressure-Induced Metallization in Energetic Materials. The American Physical Society, 67, 1-7.

[59] Wei, T., Zhu, W., Zhang, X., Li, Y.-F. and Xiao, H. (2009) Molecular Design of 1, 2, 4, 5-Tetrazine-Based High-Energy Density Materials. The Journal of Physical Chemistry $A, 113,9404-9412$. https://doi.org/10.1021/jp902295v

[60] Badders, N., Wei, C., Aldeeb, A., Rogers, W. and Mannan, M. (2006) Predicting the Impact Sensitivities of Polynitro Compounds Using Quantum Chemical Descriptors. Journal of Energetic Materials, 24, 17-33. https://doi.org/10.1080/07370650500374326

[61] Lungu, J., Oprea, C., Dumbrava, A., Enache, I., Georgescu, A., Radulescu, C., Ionita, I., Cimpoca, G. and Girtu, M. (2010) Heterocyclic Azodyes as Pigments for Dye Sensitized Solar Cells: A Combined Experimental and Theoretical Study. Journal of Optoelectronics and Advanced Materials, 12, 1969-1975.

[62] Oprea, C.I., Dumbravă, A., Enache, I., Lungu, J., Georgescu, A., Moscalu, F., Oprea, C. and Gîrțu, M.A. (2011) Role of Energy Level Alignment in Solar Cells Sensitized with a Metal-Free Organic Dye: A Combined Experimental and Theoretical Approach. Physical Status Solidi Applications and Materials Science, 208, 2467-2477. https://doi.org/10.1002/pssa.201127083

[63] Oprea, C.I., Frecuş, B., Minaev, B.F. and Gîrțu, M.A. (2011) DFT Study of Electronic Structure and Optical Properties of Some $\mathrm{Ru}$ - and Rh-Based Complexes for Dye-Sensitized Solar Cells. Molecular Physics, 109, 2511-2523. https://doi.org/10.1080/00268976.2011.621454

[64] De Angelis, F., Fantacci, S. and Selloni, A. (2008) Alignment of the Dye's Molecular Levels with the $\mathrm{TiO}_{2}$ Band Edges in Dye-Sensitized Solar Cells: A DFT-TDDFT Study. Nanotechnology, 19, 1-7. https://doi.org/10.1088/0957-4484/19/42/424002

[65] Xu, Y. and Schoonen, M.A.A. (2000) The Absolute Energy Positions of Conduction and Valence Bands of Selected Semiconducting Minerals. American Mineralogist, 
85, 543-556. https://doi.org/10.2138/am-2000-0416

[66] Peter, L.M. (2007) Characterization and Modeling of Dye-Sensitized Solar Cells. American Chemical Society, 111, 6601-6612. https://doi.org/10.1149/1.2731224

[67] Lindblad, R. (2014) Electronic Structures and Energy Level Alignment in Mesoscopic Solar Cells. Doctor of Philosophy, Uppsala University, 88. 